\title{
On the multiday haze in the Asian continental outflow: the important role of synoptic conditions combined with regional and local sources
}

\author{
Jihoon Seo ${ }^{1,2}$, Jin Young Kim ${ }^{1}$, Daeok Youn ${ }^{3}$, Ji Yi Lee ${ }^{4}$, Hwajin Kim$^{1}$, Yong Bin Lim ${ }^{1}$, Yumi Kim ${ }^{5}$, and \\ Hyoun Cher Jin ${ }^{1}$ \\ ${ }^{1}$ Green City Technology Institute, Korea Institute of Science and Technology, Seoul 02792, South Korea \\ ${ }^{2}$ School of Earth and Environmental Sciences, Seoul National University, Seoul 08826, South Korea \\ ${ }^{3}$ Department of Earth Science Education, Chungbuk National University, Cheongju 28644, South Korea \\ ${ }^{4}$ Department of Environmental Engineering, Chosun University, Gwangju 61452, South Korea \\ ${ }^{5}$ Division of Resource and Energy Assessment, Korea Environment Institute, Sejong 30147, South Korea
}

Correspondence to: Jin Young Kim (jykim@kist.re.kr)

Received: 30 December 2016 - Discussion started: 3 March 2017

Revised: 20 June 2017 - Accepted: 5 July 2017 - Published: 4 August 2017

\begin{abstract}
The air quality of the megacities in populated and industrialized regions like East Asia is affected by both local and regional emission sources. The combined effect of regional transport and local emissions on multiday haze was investigated through a synthetic analysis of $\mathrm{PM}_{2.5}$ sampled at both an urban site in Seoul, South Korea and an upwind background site on Deokjeok Island over the Yellow Sea during a severe multiday haze episode in late February 2014. Inorganic components and carbonaceous species of daily $\mathrm{PM}_{2.5}$ samples were measured, and gaseous pollutants, local meteorological factors, and synoptic meteorological conditions were also determined. A dominance of fine-mode particles $\left(\mathrm{PM}_{2.5} / \mathrm{PM}_{10} \sim 0.8\right)$, a large secondary inorganic fraction (76\%), high OC / EC (>7), and highly oxidized aerosols (oxygen-to-carbon ratio of $\sim 0.6$ and organic-mass-to-carbon ratio of $\sim 1.9$ ) under relatively warm, humid, and stagnant conditions characterize the multiday haze episode in Seoul; however, the early and late stages of the episode show different chemical compositions of $\mathrm{PM}_{2.5}$. High concentrations of sulfate in both Seoul and the upwind background in the early stage suggest a significant regional influence on the onset of the multiday haze. At the same time, high concentrations of nitrate and organic compounds in Seoul, which are local and highly correlated with meteorological factors, suggest the contribution of local emissions and secondary formation under stagnant meteorological conditions to the haze. A
\end{abstract}

slow eastward-moving high-pressure system from southern China to the East China Sea induces the regional transport of aerosols and potential gaseous precursors for secondary aerosols from the North China Plain in the early stage but provides stagnant conditions conducive to the accumulation and the local formation of aerosols in the late stage. A blocking ridge over Alaska that developed during the episode hinders the zonal propagation of synoptic-scale systems and extends the haze period to several days. This study provides chemical insights into haze development sequentially by regional transport and local sources, and shows that the synoptic condition plays an important role in the dynamical evolution of long-lasting haze in the Asian continental outflow region.

\section{Introduction}

Haze is an atmospheric phenomenon causing visibility impairment that primarily results from scattering and absorbing light by particulate matter (PM) in ambient air, such as dust, smoke, and other organic and inorganic aerosols. Haze often accompanies high concentrations of gas pollutants and finemode PM with a diameter of $2.5 \mu \mathrm{m}$ or less $\left(\mathrm{PM}_{2.5}\right)$ and has adverse effects on the human respiratory and cardiovascular systems (Pope and Dockery, 2006; WHO, 2006; EPA, 2012). 
In addition, low visibility and solar dimming by severe haze could pose hazards to both land and air traffic, reduce crop yields (Chameides et al., 1999), and affect both meteorology and climate by changing the radiation budget (Ramanathan et al., 2001; J. Wang et al., 2014).

Recently the East Asian countries, especially China, have suffered from regional-scale prolonged haze during the cold season (Tao et al., 2012; Wang et al., 2014a; Jiang et al., 2015) and have thus faced serious public health and economic risks (Gao et al., 2015). Such severe long-lasting events are driven by the combination of synoptic meteorological conditions and secondary aerosol formation processes (Zhao et al., 2013; Zheng et al., 2015). Chemical speciation and source apportionment studies have shown that secondary aerosols rather than primary aerosols mostly contribute to the fine particles during prolonged haze (Huang et al., 2014; Sun et al., 2014; Zhang et al., 2014). Synoptic meteorological conditions conducive to the accumulation of the primary pollutants and gaseous precursors for secondary aerosols, regional transport among the megacities, and secondary aerosol formation through heterogeneous surface reactions or multiphase aqueous chemistry play critical roles in the development and sustentation of widespread and durable haze (Zhao et al., 2013; Wang et al., 2014b; Zheng et al., 2015).

Long-lasting haze with high $\mathrm{PM}_{2.5}$ concentrations has also been a matter of concern in South Korea, the geographical neighbor of China across the Yellow Sea (Kang et al., 2004, 2013; Park et al., 2013, 2015; Shin et al., 2014; J. H. Kim et al., 2016). The multiday PM pollution in the capital city of Seoul has steadily occurred during the cold season (Oh et al., 2015) despite the decrease in PM concentration since the 2000s owing to the reduction in diesel vehicle emissions and fugitive dust (Ahmed et al., 2015; Ghim et al., 2015).

The cause of the multiday haze episodes in Seoul could be quite complex since the air quality in Seoul and its metropolitan area (Seoul metropolitan area; SMA) could be affected by both local emissions and transport by the Asian continental outflow. The SMA is a highly populated and industrialized region with a population of 25 million people, 9 million vehicles, and $49 \%$ of the gross domestic product (GDP) although it is only $12 \%$ of South Korea's land area. A large proportion of South Korea's emissions of primary pollutants and secondary aerosol contributors are emitted from the SMA: $38 \%$ of carbon monoxide (CO), $32 \%$ of volatile organic compounds (VOCs), $26 \%$ of nitrogen oxides $\left(\mathrm{NO}_{x}\right)$, and $19 \%$ of ammonia $\left(\mathrm{NH}_{3}\right.$; NIER, 2015). The fraction of sulfur oxide $\left(\mathrm{SO}_{x}\right)$ emission in the SMA is small (only $9 \%$ of South Korea's total emissions) due to the expansion of natural gas and low-sulfur fuel usage since the late 1990s (Kang et al., 2006). In addition to domestic emissions, the background air pollution levels in the SMA could be affected by massive emissions in the Chinese eastern coastal region. The emission intensities for Jing-Jin-Ji (Beijing-Tianjin-Hebei), Shandong, Jiangsu, and Shanghai (a total area of $482600 \mathrm{~km}^{2}$ ) in 2010 were estimated as high as $98.1 \mathrm{t} \mathrm{km}^{-2}$ for $\mathrm{CO}, 17.4 \mathrm{tkm}^{-2}$ for $\mathrm{NO}_{x}, 14.3 \mathrm{t} \mathrm{km}^{-2}$ for sulfur dioxide $\left(\mathrm{SO}_{2}\right), 13.7 \mathrm{t} \mathrm{km}^{-2}$ for VOCs, and $4.8 \mathrm{t} \mathrm{km}^{-2}$ for $\mathrm{NH}_{3}$. These are much larger than those for South Korea (an area of $100200 \mathrm{~km}^{2}$ ) estimated as $8.4 \mathrm{t} \mathrm{km}^{-2}$ for $\mathrm{CO}, 10.6 \mathrm{t} \mathrm{km}^{-2}$ for $\mathrm{NO}_{x}, 4.2 \mathrm{t} \mathrm{km}^{-2}$ for $\mathrm{SO}_{2}, 8.5 \mathrm{t} \mathrm{km}^{-2}$ for VOCs, and $1.9 \mathrm{t} \mathrm{km}^{-2}$ for $\mathrm{NH}_{3}(\mathrm{Li}$ et al., 2017). The prevailing midlatitude westerlies combined with the massive emissions in China often result in the transboundary transport of regional pollutants to the Korean Peninsula (Kim et al., 2007, 2014; Lee et al., 2013). A recent source apportionment study on $\mathrm{PM}_{2.5}$ in Seoul has estimated that, on average, about $30 \%$ of $\mathrm{PM}_{2.5}$ mass is attributed to regional sources, excluding potential contributions from transported secondary aerosol precursors (B. M. Kim et al., 2016).

In such a complex source region, synoptic meteorological conditions could be an important factor in long-lasting haze pollution. A composite analysis for the multiday high $\mathrm{PM}_{10}$ episodes in Seoul shows that a strong high-pressure system over the eastern Chinese-Korean peninsula region, which slowly developed and moved from central China, could trap the pollutants over China within the boundary layer and gradually spread them into the downwind region by weak westerlies (Oh et al., 2015). Although Oh et al. focused more on the regional effects caused by such a synoptic pattern, the stagnant high-pressure system could also provide a conducive environment for the accumulation of primary pollutants and secondary aerosol precursors. Subsidence in the high-pressure region strengthens an inversion layer, suppresses boundary layer growth, and reduces boundary layer height (BLH; Stull, 1988; Angevine et al., 1994). In addition, local meteorological factors like insolation, temperature, and relative humidity $(\mathrm{RH})$, which affect the chemical processes for secondary aerosol formation and particle aging (Seinfeld and Pandis, 2006), are also controlled by synoptic-scale meteorology (Sun et al., 2014; Zheng et al., 2015). Therefore, the influence of synoptic conditions on the multiday PM pollution needs to be considered together with the local and regional sources.

In late February 2014, South Korea experienced severe multiday haze (Shin et al., 2014; Park et al., 2015; J. H. Kim et al., 2016). We collected daily PM samples at both an urban site in Seoul and an upwind background site on Deokjeok Island over the Yellow Sea during the haze and the following clean periods. Because PM in Seoul is significantly affected by local sources while PM on Deokjeok Island is mostly attributed to regional sources, the comparison between the two sites is our approach for source appointment. In this work, we explored the combined effect of local emissions, regional transport, and synoptic conditions on the prolonged fine-particulate pollution in the Asian continental outflow region. Chemical compositions, including inorganic and carbonaceous species of $\mathrm{PM}_{2.5}$, at both sites during the haze and clean periods were characterized. In addition, the temporal evolution of the haze episode was examined with changes in chemical components and meteorological factors. Finally, 
(a) Geographical locations

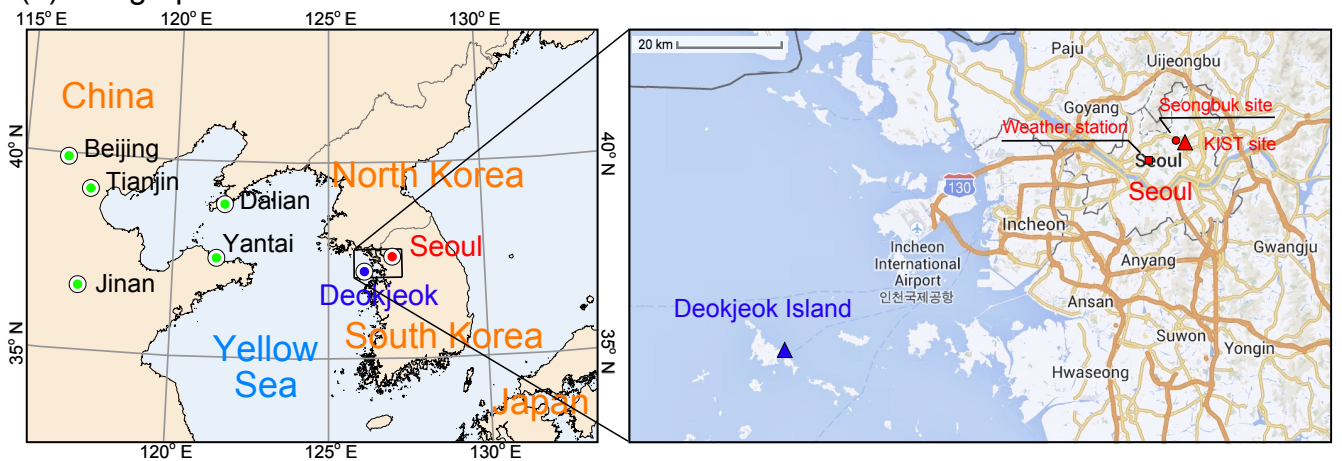

(b) Measurements of $\mathrm{PM}_{10}$ and $\mathrm{PM}_{2.5}$ in South Korea

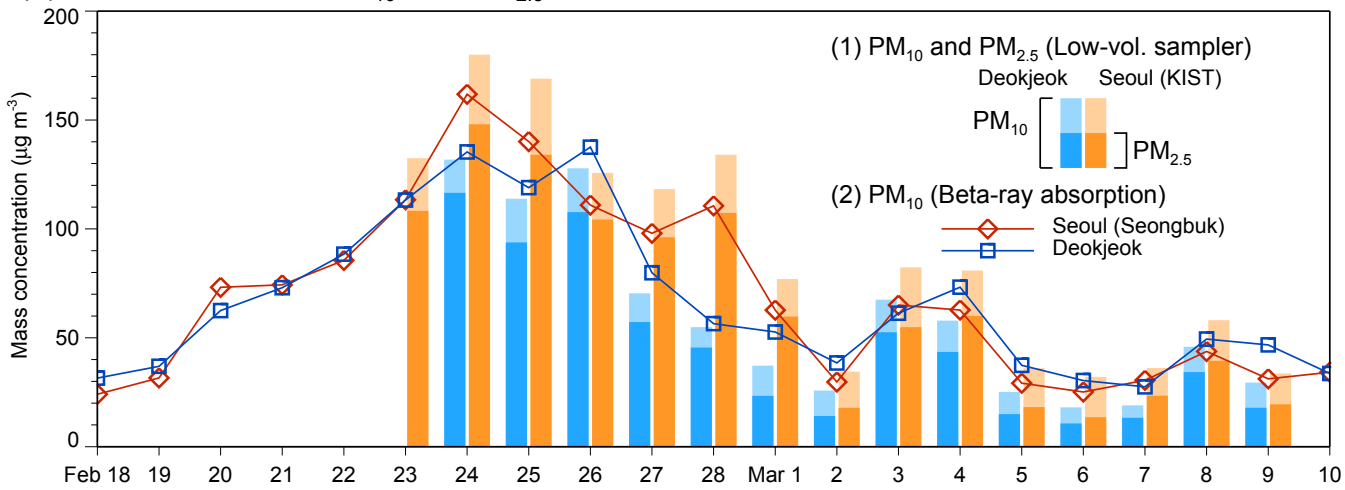

(c) $\mathrm{PM}_{25}$ concentrations in Chinese cities

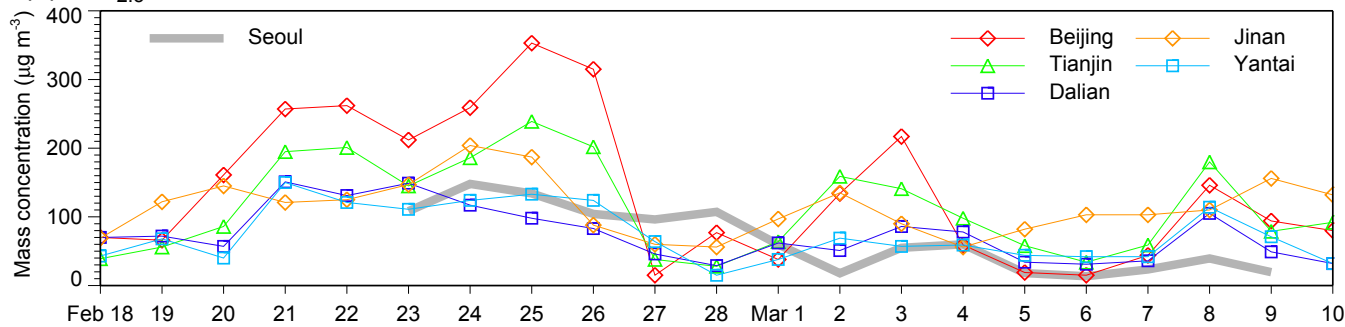

Figure 1. (a) Geographical locations of filter sampling sites (KIST site in Seoul and the Deokjeok site), KMOE air quality monitoring sites (Seongbuk site in Seoul and the Deokjeok site), and KMA weather station in Seoul. (b) Daily mass concentrations of $\mathrm{PM}_{10}$ and $\mathrm{PM}_{2.5}$ sampled at the KIST site in Seoul and the Deokjeok site (bars) during the multiday haze episode and following the clean period in late February to early March 2014. Red diamonds and blue squares with solid lines denote $24 \mathrm{~h}$ averages of $\mathrm{PM}_{10}$ concentration measured by beta-ray absorption at the Seongbuk site in Seoul and at the Deokjeok site, respectively. (c) Daily $\mathrm{PM}_{2.5}$ concentrations in the five Chinese cities of Beijing, Tianjin, Dalian, Jinan, and Yantai (http://www.tianqihoubao.com/aqi/).

relevant synoptic conditions that induced the multiday haze event are further discussed.

\section{Measurement and data}

\subsection{Sampling overview}

Daily $\mathrm{PM}_{2.5}$ and $\mathrm{PM}_{10}$ samplings were conducted at the urban site located inside the Korea Institute of Science and Technology (KIST) in northeastern Seoul $\left(37.603^{\circ} \mathrm{N}\right.$, $127.047^{\circ} \mathrm{E} ; 58 \mathrm{~m}$ a.s.l.) and the background site located on Deokjeok Island over the Yellow Sea $\left(37.233^{\circ} \mathrm{N}\right.$, $126.149^{\circ} \mathrm{E} ; 185 \mathrm{~m}$ a.s.1.) between 23 February and 9 March 2014 (Fig. 1a). The sampling period includes the multiday haze pollution in late February and the following clean-air period in early March. The KIST site is located downwind of the downtown core and surrounded by a small urban forest (about 60 ha) and a residential area. Thus, the measurement at this site represents the particulate air quality of Seoul influenced by both local and regional sources. The Deok- 
jeok site located on the offshore island is about $90 \mathrm{~km}$ westsouthwest from the KIST site in Seoul. Since significant emission sources do not exist on the island, the measurement at the Deokjeok site mainly represents regional sources.

The daily sampling started at 09:00 local time (LT) and was carried out for $24 \mathrm{~h}$ on each day. The $\mathrm{PM}_{2.5}$ samples for the mass measurement and ionic analysis were collected on pre-weighted $47 \mathrm{~mm}$ Teflon filters (Zefluor ${ }^{\mathrm{TM}}$; Pall Corporation, Port Washington, NY) using a Teflon-coated aluminum cyclone with a cut size of $2.5 \mu \mathrm{m}$ and a flow rate of $16.7 \mathrm{~L} \mathrm{~min}^{-1}$ (URG Corporation, Chapel Hill, NC). PM with a diameter of $10 \mu \mathrm{m}$ or less $\left(\mathrm{PM}_{10}\right)$ was also collected in the same way to compare the mass concentration with $\mathrm{PM}_{2.5}$. The $\mathrm{PM}_{2.5}$ sample for carbonaceous and organic compound analyses is collected on $203 \times 254 \mathrm{~mm}$ quartz fiber filters (Whatman Inc., Maidstone, UK) using a high-volume air sampler with a flow rate of $1000 \mathrm{~L} \mathrm{~min}^{-1}$ (Andersen Instruments Inc., Atlanta, GA). All samples were sealed immediately after collection and stored in freezers to prevent possible contamination.

Note that the $\mathrm{PM}_{2.5}$ sampling conducted in this study could result in artifacts of carbonaceous species. Firstly, we used the high-volume air sampler for carbon analyses, while the total mass and ion concentrations were obtained by the low-volume air sampler. Secondly, we did not employ a preceding organic denuder or backup filters in the high-volume air sampler for the correction of positive artifacts (by adsorption of organic vapor) and negative artifacts (by volatilization of semivolatile materials) in measured OC. Although the positive artifacts are thought to be larger than the negative artifacts (Chow et al., 2010; D. Kim et al., 2016), the high-volume air sampler tends to underestimate particle concentrations (Lagler et al., 2011; Aggarwal et al., 2013), and thus the measurement by the high-volume air sampler may partly reduce such positive artifacts as recently estimated by D. Kim et al. (2016). However, the aging and oxidation properties and source characteristics of measured aerosols can still be altered by the potential loss of semivolatile organic compounds. In this study, we therefore used organic compounds for qualitative comparisons between different places and periods rather than for quantitative analysis.

\subsection{Analytical procedure}

The mass concentrations of $\mathrm{PM}_{2.5}$ and $\mathrm{PM}_{10}$ were measured by the Mettler MT5 microbalance (Mettler-Toledo, Greifensee, Switzerland) with a precision of $1 \mu \mathrm{g}$ after $24 \mathrm{~h}$ of standing on the Teflon filter sample in a desiccator. Then, the sample was sonicated in a mixture of $0.5 \mathrm{~mL}$ of ethanol and $14.5 \mathrm{~mL}$ of distilled and deionized water for $30 \mathrm{~min}$ to measure water-soluble ion concentrations in $\mathrm{PM}_{2.5}$. Concentrations of sulfate $\left(\mathrm{SO}_{4}^{2-}\right)$, nitrate $\left(\mathrm{NO}_{3}^{-}\right)$, chloride $\left(\mathrm{Cl}^{-}\right)$, ammonium $\left(\mathrm{NH}_{4}^{+}\right)$, potassium $\left(\mathrm{K}^{+}\right)$, calcium $\left(\mathrm{Ca}^{2+}\right)$, sodium $\left(\mathrm{Na}^{+}\right)$, and magnesium $\left(\mathrm{Mg}^{2+}\right)$ were measured by the Dionex 2000i/SP ion chromatograph (Dionex, Sunny- vale, CA). To analyze organic carbon (OC) and element carbon (EC) in $\mathrm{PM}_{2.5}$, a piece of the quartz fiber filter $(10 \times 15 \mathrm{~mm})$ was used with a thermal/optical carbon aerosol analyzer (Sunset Laboratory, Tigard, OR) based on the National Institute for Occupational Safety and Health (NIOSH) method 5040 (Birch and Cary, 1996).

To identify and measure the concentrations of individual organic compounds, one-half of the quartz fiber filter was used and ultrasonicated twice in each of two $50 \mathrm{~mL}$ mixtures of dichloromethane and methanol $(3: 1 ; v / v)$ in sequential order, each for $30 \mathrm{~min}$ (total volume of the solution $100 \mathrm{~mL}$ ). The filter composite was spiked with 11 isotopically labeled surrogated standards and blown down to $100 \mathrm{~mL}$ with a Zymark TurboVap 500 concentrator (Zymark Corporation, Hopkinton, MA) under a pure nitrogen stream at $40^{\circ} \mathrm{C}$. This process induces low recovery rates $(\sim 70 \%)$ of relatively low molecular weight compounds (e.g., $n$-alkanes lighter than $\mathrm{C}_{20}$ and PAHs lighter than anthracene), and we excluded these compounds from further analyses. The extract was filtered by syringe with a PTFE membrane filter (ID $25 \mathrm{~mm}$; pore size $0.45 \mu \mathrm{m}$; Pall Corporation) and further reduced by gentle solvent evaporation with a stream of high-purity nitrogen to a final volume of $0.5 \pm 0.1 \mathrm{~mL}$. The GC-MS analysis was carried out on a Hewlett Packard 7890A gas chromatograph coupled to a 5975C mass selective detector (Agilent, Palo Alto, CA) in the synchronous selected ion monitoring (SIM scan) mode. A $1 \mu \mathrm{L}$ sample was injected on splitless mode at $240^{\circ} \mathrm{C}$. The mass spectrometer was operated on electron impact (EI) mode at $70 \mathrm{eV}$ and scanned from 40 to $550 \mathrm{Da}$ at the source temperature of $230^{\circ} \mathrm{C}$.

The organic compounds were classified into five groups: $n$-alkanes, polycyclic aromatic hydrocarbons (PAHs), monocarboxylic acids, sugars, and dicarboxylic acids. These are $17 n$-alkanes: $\mathrm{C}_{20}-\mathrm{C}_{36}$ and fifteen PAHs: phenanthrene (PHE), anthracene (ANT), fluoranthene (FLA), pyrene (PYR), benz $[a]$ anthracene (BaA), chrysene (CHR), benzo[b]fluoranthene (BbF), benzo[e]pyrene $(\mathrm{BeP})$, benzo $[a]$ pyrene $(\mathrm{BaP})$, perylene (PER), 1,3,5triphenylbenzene (TPB), indeno[1,2,3-cd]pyrene (IcdP), dibenz $[a, h]$ anthracene (DahA), benzo[ $g h i]$ perylene (BghiP), and coronene (COR). There are 19 monocarboxylic acids $\mathrm{C}_{6}-\mathrm{C}_{20}$, including oleic or elaidic acids $\left(\mathrm{C}_{18: 1}\right)$ and cis-pinonic acid, and 9 sugars: arabinose, ribose, levoglucosan, xylose, fructose, mannose, galactose, glucose, and sucrose. There are also 19 dicarboxylic acids: malonic acid, methylmalonic acid, maleic acid, methylmaleic acid, succinic acid, methylsuccinic acid, fumaric acid, glutaric acid, 2-methylglutaric acid, D-malic acid, adipic acid, pimelic acid, phthalic acid, suberic acid, isophthalic acid, terephthalic acid, azelaic acid, sebacic acid, and undecanedioic acid. A detailed description of the aforementioned chemical analyses can be found in Choi et al. (2016). 


\subsection{Data}

The Korean Ministry of Environment (KMOE) provides $1 \mathrm{~h}$ average concentrations of $\mathrm{PM}_{10}, \mathrm{SO}_{2}, \mathrm{NO}_{2}, \mathrm{CO}$, and ozone $\left(\mathrm{O}_{3}\right)$ at 257 urban sites, 19 suburban sites, and 3 background sites over South Korea (NIER, 2016). The measurements of each species are conducted by the beta-ray absorption method for $\mathrm{PM}_{10}$, the pulse ultraviolet fluorescence method for $\mathrm{SO}_{2}$, the chemiluminescent method for $\mathrm{NO}_{2}$, the nondispersive infrared method for $\mathrm{CO}$, and the ultraviolet photometric method for $\mathrm{O}_{3}$. In the present study, we employ hourly data for $\mathrm{PM}_{10}$ and other gaseous species measured at the Seongbuk site $(1.7 \mathrm{~km}$ northwest from the PM sampling site inside the KIST) in Seoul and the Deokjeok site (next to the PM sampling site) to analyze and compare with the sampling data (Fig. 1a). As shown in Fig. 1b, the mass concentrations of $\mathrm{PM}_{10}$ from daily filter samples in Seoul (KIST) and Deokjeok are consistent with the daily $\mathrm{PM}_{10}$ concentrations measured by beta-ray absorption in Seoul (Seongbuk) and Deokjeok ( $r^{2}=0.99$ in Seoul and $r^{2}=0.97$ in Deokjeok). Also, we select 247 sites based on data availability for the analysis period to explore changes in the spatial distribution of $\mathrm{PM}_{10}$ over South Korea during the prolonged haze episode. Daily $\mathrm{PM}_{2.5}$ concentrations in the five Chinese cities of Beijing, Tianjin, Dalian, Jinan, and Yantai were obtained from a public weather website (http://www.tianqihoubao.com/aqi/).

Hourly meteorological variables, such as temperature, $\mathrm{RH}$, and wind speed, observed at the Seoul weather station $(8 \mathrm{~km}$ southwest from the KIST site) provided by the Korea Meteorological Administration (KMA) are additionally used in this study (Fig. 1a). To investigate BLH in Seoul, the European Centre for Medium-Range Weather Forecasts Reanalysis Interim (ERA-Interim) data at a grid point within Seoul $\left(37.5^{\circ} \mathrm{N}, 127.0^{\circ} \mathrm{E} ; 12.3 \mathrm{~km}\right.$ south-southwest from the KIST site) are employed. To investigate synoptic conditions during the haze period, the geopotential height and wind fields at 850 and $500 \mathrm{hPa}$ derived from the ERA-Interim data together with aerosol optical depth (AOD) at $550 \mathrm{~nm}$ from the Moderate Resolution Imaging Spectroradiometer (MODIS) onboard the Terra and Aqua satellites are used.

\section{Results and discussion}

\subsection{Multiday haze episode in Seoul}

On 20 February 2014, the daily PM $_{10}$ concentration in Seoul (by beta-ray absorption) first exceeded the World Health Organization (WHO) $24 \mathrm{~h}$ mean guideline of $50 \mathrm{\mu g} \mathrm{m}^{-3}$ (WHO, 2006). It increased over the South Korean $24 \mathrm{~h}$ mean standard of $100 \mu \mathrm{g} \mathrm{m}^{-3}$ (NIER, 2016) from 23 to 28 February, and fell back below $50 \mu \mathrm{g} \mathrm{m}^{-3}$ on 2 March. A PM 10 concentration higher than $50 \mu \mathrm{g} \mathrm{m}^{-3}$ was again recorded from 3 to 4 March (Fig. 1b). The daily $\mathrm{PM}_{2.5}$ concentration in Seoul (by filter sampling) shows a similar temporal pattern. The
$\mathrm{PM}_{2.5}$ mass concentration in Seoul recorded its highest value of $148 \mu \mathrm{g} \mathrm{m}^{-3}$ on 24 February and stayed near $100 \mu \mathrm{g} \mathrm{m}^{-3}$ until 28 February (Fig. 1b). The measured $\mathrm{PM}_{2.5}$ in Seoul exceeded not only the WHO $24 \mathrm{~h}$ mean guideline of $25 \mu \mathrm{g} \mathrm{m}^{-3}$ (WHO, 2006) but also the South Korean $24 \mathrm{~h}$ mean standard of $50 \mu \mathrm{g} \mathrm{m}^{-3}$ (NIER, 2016) for 9 days between 23 February and 4 March, except 2 March. In Deokjeok, a high concentration of $\mathrm{PM}_{2.5}$ near or higher than $100 \mu \mathrm{g} \mathrm{m}^{-3}$ continued until 26 February, but the $\mathrm{PM}_{2.5}$ level started to fall on 27 February when the $\mathrm{PM}_{2.5}$ level was still high in Seoul (Fig. 1b).

The $\mathrm{PM}_{2.5}$ mass concentration in Deokjeok was generally 70-90\% of that in Seoul throughout the measurement period. It was, however, slightly higher than that in Seoul on a day in the mid-stage of the haze (26 February) and then showed only $40-60 \%$ of that in Seoul during the following late stage of the episode (27 February to 1 March). A similar trend was reported in five upwind Chinese cities across the Yellow Sea, which also experienced high $\mathrm{PM}_{2.5}$ concentrations from 20 to 26 February and a rapid drop in the $\mathrm{PM}_{2.5}$ levels on 27 February (Fig. 1c).

The wind direction during the overall analysis period was mostly westerly or west-northwesterly, but there were easterly winds on 26 February. Considering negligible local emissions on and near Deokjeok Island, the high $\mathrm{PM}_{2.5}$ level in Deokjeok is most likely due to regional transport from China, evidenced by the high $\mathrm{PM}_{2.5}$ levels in the upwind Chinese cities (Fig. 1c) and backward trajectories during the haze period (Fig. 2a). On the other hand, the high $\mathrm{PM}_{2.5}$ level in Deokjeok on 26 February seems to result from the easterly transport of pollutants from the SMA, as shown by backward trajectories passing through the SMA before reaching Deokjeok (Fig. 2b). The high $\mathrm{PM}_{2.5}$ levels in Seoul and the low $\mathrm{PM}_{2.5}$ concentrations in Deokjeok on the following 3 days (Fig. 1b), as well as the stagnant backward trajectories (Fig. 2b), show that the prolonged haze period in Seoul not only resulted from the transboundary transport of pollutants, but could also be affected by local sources.

The durable haze widely affected PM levels over South Korea as represented in the spatial distribution of $\mathrm{PM}_{10}$ concentrations (Fig. 3). A clear western-high and eastern-low pattern in $\mathrm{PM}_{10}$ concentration appears during the haze enhancement (22-24 February), but such a westward gradient of $\mathrm{PM}_{10}$ levels becomes weaker after the appearance of a nationwide high concentration (25-27 February). $\mathrm{PM}_{10}$ concentrations finally decrease but still remain relatively high in the SMA and inland area in the last stage of the prolonged haze (28 February to 1 March). The westward PM $_{10}$ gradient with high PM concentrations at Deokjeok (Fig. 1b) before 26 February supports the regional influence in the early stage of the haze period. On the other hand, the weakened westward $\mathrm{PM}_{10}$ gradient, the high $\mathrm{PM}_{10}$ levels in the SMA and inland area, and the low PM concentrations at Deokjeok (Fig. 1b) after 26 February imply a local influence in the final stage of the haze period in Seoul. 
(a) Haze period (23-25 Feb 2014)

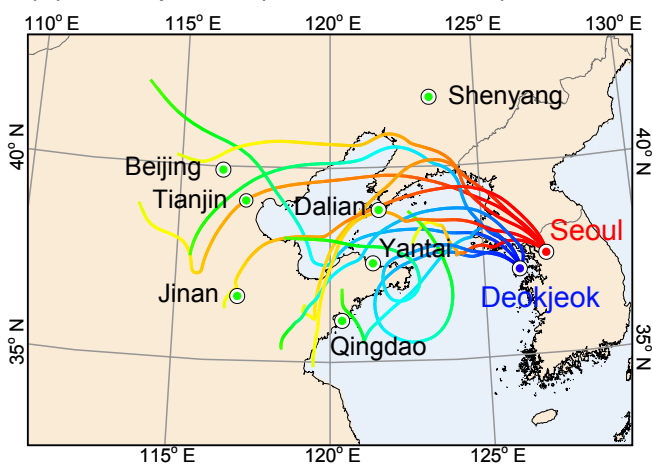

(b) Haze period (26-28 Feb 2014)

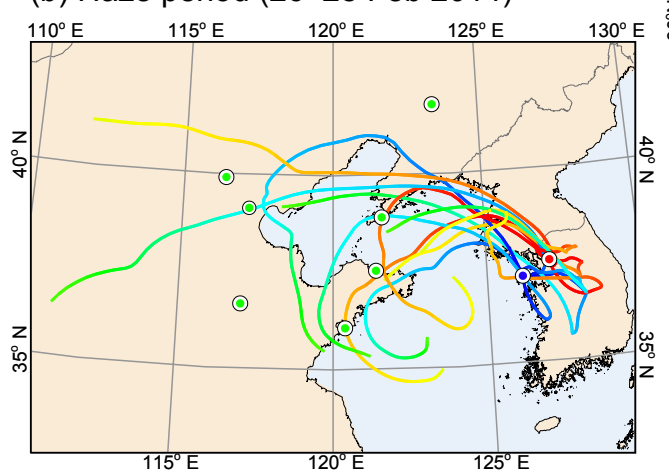

(c) Clean period (5-9 Mar 2014)

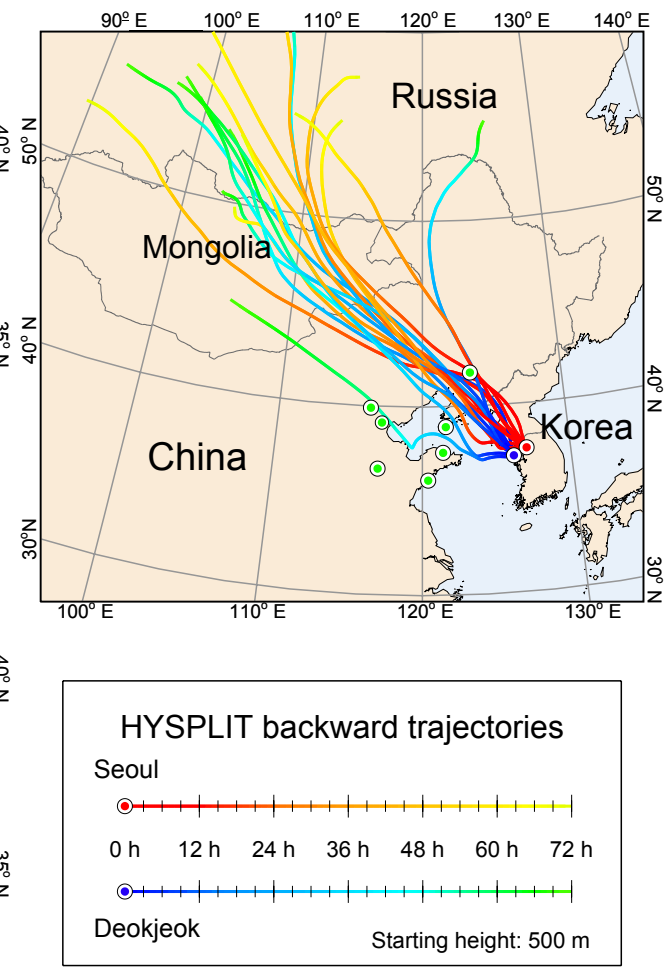

Figure 2. Backward trajectories from 500 m a.s.l. over the KIST site in Seoul (red) and the Deokjeok site (blue) at 09:00 and 21:00 local time (GMT+09:00) during (a) the early stage of haze, (b) the late stage of haze, and (c) the clean period.

\subsection{Formation of $\mathrm{PM}_{2.5}$ in Seoul and background}

The chemical speciation of $\mathrm{PM}_{2.5}$ and gaseous pollutants in Seoul and Deokjeok during the haze and clean periods reveals spatial dynamics of $\mathrm{PM}_{2.5}$ influenced by its urban and upwind background downwind of East Asia. The average chemical compositions of $\mathrm{PM}_{2.5}$ in both Seoul and Deokjeok for the haze period (23-28 February) and the following clean period (5-9 March) are presented in Fig. 4 and Tables 1-2. Different characteristics of $\mathrm{PM}_{2.5}$ between downwind urban and upwind backgrounds are revealed from the comparisons of $\mathrm{PM}_{2.5}$ compositions in Seoul and Deokjeok and summarized in Table 3. $\mathrm{PM}_{2.5}$ properties during the haze and clean periods are compared and summarized in Table 4.

\subsubsection{Local meteorological conditions in Seoul}

Seoul experienced warm, humid, and stagnant conditions within the shallow boundary layer during the haze period (Table 1 and Fig. 5e-f). The decrease in BLH $(\sim 400 \mathrm{~m})$ and low wind speed $\left(\sim 2 \mathrm{~m} \mathrm{~s}^{-1}\right)$ effectively interrupt vertical mixing and increase PM concentrations near the ground through the accumulation of primary aerosols and secondary aerosol precursors (Zheng et al., 2015). Because of the high PM concentrations, daytime visibility in Seoul was signifi- cantly reduced to its minimum value of $1.3 \mathrm{~km}$ in the morning on 25 February. As mentioned in the previous section, wind directions were mostly westerly or west-northwesterly over the measurement period, except for easterly winds only on 26 February. Therefore, the regional influences on the severe haze can be inferred from the high concentration of each chemical component (Table 1) and the backward trajectories from China (Fig. 2a-b) during the haze period in both Seoul and Deokjeok. On the other hand, the tendency toward a lower mass concentration of each aerosol component in Deokjeok than in Seoul (Table 1) implies the local contributions of both primary emissions from the SMA and secondary production from local and transported precursor gases to the long-lasting haze in Seoul.

\subsubsection{Gaseous species in Seoul and background}

Among the four gas species investigated in this study, $\mathrm{SO}_{2}$ and $\mathrm{NO}_{2}$ are important species closely related to sulfate and nitrate aerosols. The higher $\mathrm{SO}_{2}$ concentration in the haze period in Deokjeok than in Seoul (Table 1) and the much lower emission intensity of $\mathrm{SO}_{2}$ in the SMA $\left(3.1 \mathrm{t} \mathrm{km}^{-2}\right)$ than in the Chinese Yellow Sea coastal provinces (Li et al., 2017; NIER, 2015) provide evidence that $\mathrm{SO}_{2}$ in Seoul was greatly influenced by regional transport from China. On the other 
Table 1. The average and standard deviation of $\mathrm{PM}_{2.5}$ chemical compositions, related gas concentrations, and meteorological factors in Seoul and Deokjeok for the haze (23-28 February 2014) and clean (5-9 March 2014) periods.

\begin{tabular}{|c|c|c|c|c|c|c|}
\hline & \multirow[b]{2}{*}{ Components } & & \multicolumn{2}{|c|}{ Seoul } & \multicolumn{2}{|c|}{ Deokjeok } \\
\hline & & & Haze & Clean & Haze & Clean \\
\hline \multirow{3}{*}{$\begin{array}{l}\text { Mass } \\
\text { concentrations }\end{array}$} & \multirow{3}{*}{$\begin{array}{l}\mathrm{PM}_{10}\left(\mu \mathrm{g} \mathrm{m}^{-3}\right) \\
\mathrm{PM}_{2.5}\left(\mu \mathrm{g} \mathrm{m}^{-3}\right)\end{array}$} & & $143 \pm 25$ & $39 \pm 11$ & $100 \pm 35$ & $28 \pm 11$ \\
\hline & & & $116 \pm 29$ & $23 \pm 10$ & $84 \pm 31$ & $18 \pm 9$ \\
\hline & & $\mathrm{PM}_{2.5} / \mathrm{PM}_{10}$ & $0.81 \pm 0.01$ & $0.57 \pm 0.10$ & $0.84 \pm 0.03$ & $0.65 \pm 0.07$ \\
\hline \multirow{15}{*}{$\begin{array}{l}\text { Inorganic } \\
\text { species }\end{array}$} & \multirow{8}{*}{\multicolumn{2}{|c|}{$\begin{array}{l}\mathrm{SO}_{4}^{2-}\left(\mu \mathrm{g} \mathrm{m}^{-3}\right) \\
\mathrm{NO}_{3}^{-}\left(\mu \mathrm{g} \mathrm{m}^{-3}\right) \\
\mathrm{Cl}^{-}\left(\mu \mathrm{g} \mathrm{m}^{-3}\right) \\
\mathrm{NH}_{4}^{+}\left(\mu \mathrm{g} \mathrm{m}^{-3}\right) \\
\mathrm{K}^{+}\left(\mu \mathrm{g} \mathrm{m}^{-3}\right) \\
\mathrm{Ca}^{2+}\left(\mu \mathrm{g} \mathrm{m}^{-3}\right) \\
\mathrm{Mg}^{2+}\left(\mu \mathrm{g} \mathrm{m}^{-3}\right) \\
\mathrm{Na}^{+}\left(\mu \mathrm{g} \mathrm{m}^{-3}\right)\end{array}$}} & $34.9 \pm 9.1$ & $3.9 \pm 1.4$ & $29.2 \pm 12.4$ & $4.7 \pm 2.6$ \\
\hline & & & $32.8 \pm 8.4$ & $4.6 \pm 4.2$ & $11.4 \pm 8.5$ & $2.8 \pm 3.0$ \\
\hline & & & $1.1 \pm 0.4$ & $0.3 \pm 0.2$ & $0.6 \pm 0.6$ & $0.2 \pm 0.1$ \\
\hline & & & $21.6 \pm 4.3$ & $2.7 \pm 1.6$ & $14.4 \pm 6.0$ & $2.4 \pm 1.8$ \\
\hline & & & $0.9 \pm 0.2$ & $0.2 \pm 0.1$ & $0.7 \pm 0.3$ & $0.2 \pm 0.1$ \\
\hline & & & $0.3 \pm 0.1$ & $0.1 \pm 0.0$ & $0.2 \pm 0.1$ & $0.1 \pm 0.0$ \\
\hline & & & $0.1 \pm 0.0$ & $0.1 \pm 0.0$ & $0.1 \pm 0.0$ & $0.1 \pm 0.1$ \\
\hline & & & $0.1 \pm 0.0$ & $0.1 \pm 0.0$ & $0.1 \pm 0.1$ & $0.1 \pm 0.1$ \\
\hline & \multirow{7}{*}{$\operatorname{SIA}\left(\mu \mathrm{g} \mathrm{m}^{-3}\right)$} & SOR & $0.44 \pm 0.04$ & $0.15 \pm 0.03$ & $0.39 \pm 0.04$ & $0.20 \pm 0.06$ \\
\hline & & {$\left[\mathrm{NH}_{4}^{+}\right] /\left[\mathrm{SO}_{4}^{2-}\right]$} & $1.68 \pm 0.16$ & $1.74 \pm 0.38$ & $1.34 \pm 0.30$ & $1.29 \pm 0.25$ \\
\hline & & & $89 \pm 21$ & $11 \pm 7$ & $55 \pm 23$ & $10 \pm 7$ \\
\hline & & SIA / PM 2.5 & $0.76 \pm 0.07$ & $0.47 \pm 0.09$ & $0.65 \pm 0.04$ & $0.51 \pm 0.10$ \\
\hline & & $\mathrm{SO}_{4}^{2-} / \mathrm{PM}_{2.5}$ & $0.30 \pm 0.04$ & $0.18 \pm 0.04$ & $0.34 \pm 0.05$ & $0.26 \pm 0.03$ \\
\hline & & $\mathrm{NO}_{3}^{-} / \mathrm{PM}_{2.5}$ & $0.28 \pm 0.03$ & $0.18 \pm 0.07$ & $0.13 \pm 0.07$ & $0.13 \pm 0.07$ \\
\hline & & $\mathrm{NH}_{4}^{+} / \mathrm{PM}_{2.5}$ & $0.18 \pm 0.01$ & $0.11 \pm 0.02$ & $0.17 \pm 0.01$ & $0.12 \pm 0.03$ \\
\hline \multirow{6}{*}{$\begin{array}{l}\text { Carbonaceous } \\
\text { species }\end{array}$} & \multirow[t]{4}{*}{$\mathrm{OC}\left(\mu \mathrm{g} \mathrm{m}^{-3}\right)$} & & $14.4 \pm 2.5$ & $4.9 \pm 0.8$ & $8.6 \pm 2.9$ & $2.7 \pm 0.6$ \\
\hline & & $\operatorname{POC}\left(\mu \mathrm{g} \mathrm{m}^{-3}\right)^{\mathrm{a}}$ & $5.7+0.7$ & $3.9+0.6$ & $2.5+0.6$ & $1.4+0.8$ \\
\hline & & $\operatorname{SOC}\left(\mu \mathrm{g} \mathrm{m}^{-3}\right)^{\mathrm{a}}$ & $8.7+2.2$ & $1.0+1.2$ & $6.1+2.6$ & $1.3+0.9$ \\
\hline & & $\mathrm{SOC} / \mathrm{OC}^{\mathrm{a}}$ & $0.60 \pm 0.06$ & $0.19 \pm 0.18$ & $0.69 \pm 0.10$ & $0.47 \pm 0.28$ \\
\hline & \multirow{2}{*}{$\mathrm{EC}\left(\mu \mathrm{g} \mathrm{m}^{-3}\right)$} & & $2.0 \pm 0.2$ & $1.4 \pm 0.2$ & $1.2 \pm 0.3$ & $0.7 \pm 0.4$ \\
\hline & & $\mathrm{OC} / \mathrm{EC}$ & $7.3 \pm 1.1$ & $3.7 \pm 1.1$ & $7.4 \pm 1.7$ & $4.9 \pm 2.0$ \\
\hline \multirow{4}{*}{$\begin{array}{l}\text { Gaseous } \\
\text { species }\end{array}$} & $\mathrm{SO}_{2}(\mathrm{ppb})$ & & $10.6 \pm 1.5$ & $5.0 \pm 0.5$ & $11.3 \pm 3.4$ & $4.5 \pm 2.1$ \\
\hline & $\mathrm{NO}_{2}(\mathrm{ppb})$ & & $68.1 \pm 11.7$ & $30.0 \pm 10.5$ & $11.1 \pm 9.5$ & $1.1 \pm 0.2$ \\
\hline & $\mathrm{CO}(\mathrm{ppm})$ & & $1.1 \pm 0.2$ & $0.4 \pm 0.1$ & $0.7 \pm 0.1$ & $0.3 \pm 0.1$ \\
\hline & $\mathrm{O}_{3}(\mathrm{ppb})$ & & $16.8 \pm 7.6$ & $28.6 \pm 6.7$ & $57.3 \pm 9.5$ & $48.6 \pm 0.7$ \\
\hline \multirow{5}{*}{$\begin{array}{l}\text { Meteorological } \\
\text { factors }\end{array}$} & Temperature $\left({ }^{\circ} \mathrm{C}\right)$ & & $6.2 \pm 2.1$ & $0.7 \pm 1.1$ & - & - \\
\hline & Relative humidity (\%) & & $55 \pm 8$ & $49 \pm 10$ & - & - \\
\hline & Wind speed $\left(\mathrm{m} \mathrm{s}^{-1}\right)$ & & $2.3 \pm 0.5$ & $3.4 \pm 0.5$ & - & - \\
\hline & Boundary layer height (m) & & $380 \pm 60^{\mathrm{b}}$ & $1000 \pm 140^{\mathrm{b}}$ & $140 \pm 80^{c}$ & $980 \pm 240^{\mathrm{c}}$ \\
\hline & Daytime (07:00-18:00) visibility $(\mathrm{km})$ & & $3.4 \pm 1.1$ & $17.1 \pm 2.6$ & - & - \\
\hline
\end{tabular}

hand, the significantly higher concentration of $\mathrm{NO}_{2}$ in Seoul than in Deokjeok, not only during the haze period but also during the clean period (Table 1), is attributed to the high $\mathrm{NO}_{x}$ emissions in the SMA $\left(23.3 \mathrm{t} \mathrm{km}^{-2}\right)$ from vehicles and industrial combustion sources (NIER, 2015).

The high $\mathrm{NO}_{x}$ emissions in the SMA are presumably a major factor in the different $\mathrm{O}_{3}$ levels between Seoul and Deokjeok. In general, the $\mathrm{O}_{3}$ level in Seoul is lower than in Deokjeok due to titration effects by substantial emissions of $\mathrm{NO}_{x}$ in the SMA (Seo et al., 2014). In Seoul, the haze-period $\mathrm{O}_{3}$ level is lower than the clean period (Table 1) due to enhanced titration in high $\mathrm{NO}_{x}$ conditions. However, Deokjeok shows a higher $\mathrm{O}_{3}$ concentration in the haze period than in the clean period (Table 1). This higher $\mathrm{O}_{3}$ level during the haze may result from enhanced $\mathrm{O}_{3}$ production due to the slightly increased $\mathrm{NO}_{2}$ concentration by regional transport (Lee et al., 2014) and/or the transport of $\mathrm{O}_{3}$ itself (Oh et al., 2010; Seo et al., 2014).

$\mathrm{CO}$, which is an incomplete combustion product of fossil fuels or biomass and biofuels, is affected by both local emissions in the SMA and regional transport from China; it thus shows a higher concentration in Seoul than in Deokjeok and in the haze period than in the clean period (Table 1). 
(a) 21 Feb 2014

(b) 22 Feb 2014

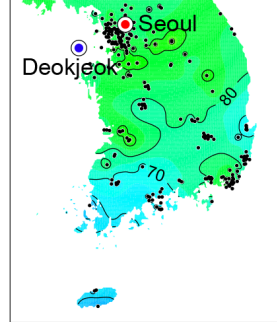

(c) 23 Feb 2014

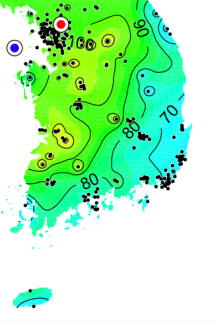

(d) 24 Feb 2014

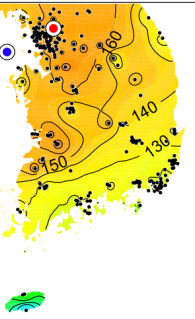

(e) 25 Feb 2014

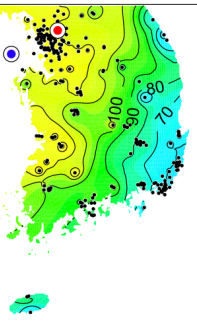

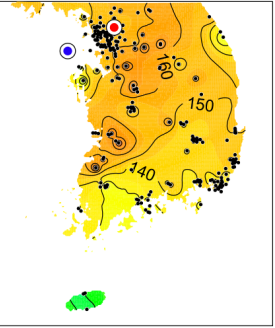

(f) 26 Feb 2014

(g) 27 Feb 2014

(h) 28 Feb 2014

(i) 1 Mar 2014

(j) 2 Mar 2014

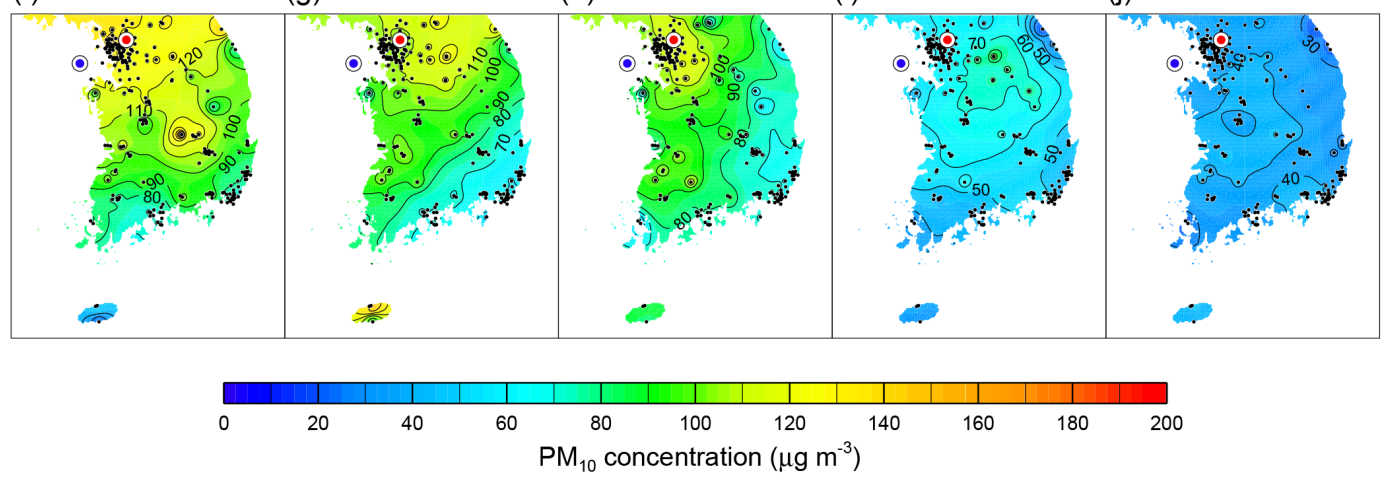

Figure 3. Spatial distribution of $\mathrm{PM}_{10}$ concentration for the period 21 February to 2 March 2014 using data from 247 air quality monitoring sites (black dots) in South Korea.

(a) Seoul - haze $\left(116 \mu \mathrm{g} \mathrm{m}^{-3}\right)$

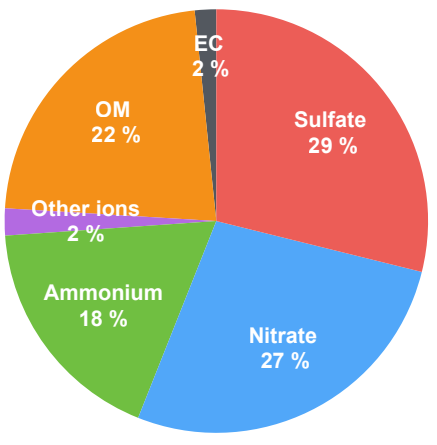

(c) Seoul - clean $\left(23 \mathrm{\mu g} \mathrm{m}^{-3}\right)$

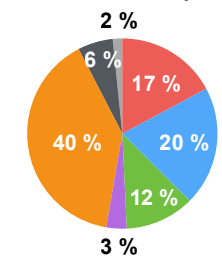

$\begin{array}{ll}\text { Sulfate } & \text { Nitrate } \\ \text { OM } & \text { EC }\end{array}$ (b) Deokjeok - haze (84 $\left.\mathrm{gg} \mathrm{m}^{-3}\right)$

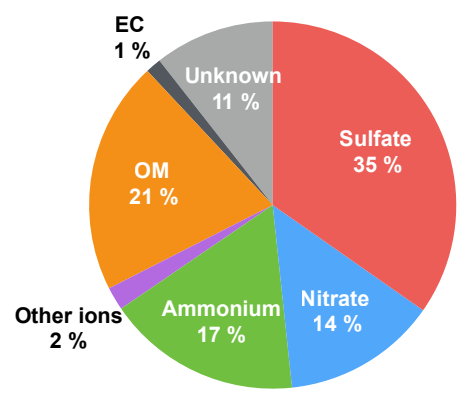

(d) Deokjeok - clean $\left(18 \mu \mathrm{g} \mathrm{m}^{-3}\right)$

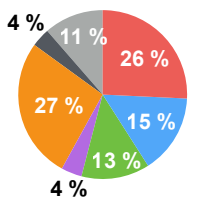

Ammonium

Unknown

Figure 4. Mass fraction (\%) of each component to the total $\mathrm{PM}_{2.5}$ mass in Seoul and Deokjeok during the haze and clean periods. The size of each chart is proportional to the averaged $\mathrm{PM}_{2.5}$ mass concentration. OM is estimated by measured OC and the $\mathrm{OM} / \mathrm{OC}$ ratios of total identified organic compounds ( $\sim 5 \%$ of total OM). 
Table 2. The average and standard deviation of analyzed organic compound concentrations and diagnostic ratios in Seoul and Deokjeok for the haze (23-28 February 2014) and clean (5-9 March 2014) periods.

\begin{tabular}{|c|c|c|c|c|c|}
\hline \multirow[b]{2}{*}{ Organic compounds } & \multirow[b]{2}{*}{ Components } & \multicolumn{2}{|c|}{ Seoul } & \multicolumn{2}{|c|}{ Deokjeok } \\
\hline & & Haze & Clean & Haze & Clean \\
\hline \multirow{3}{*}{$\mathrm{OM}\left(\mu \mathrm{g} \mathrm{m}^{-3}\right)^{\mathrm{b}}$} & & $27.1 \pm 5.3$ & $9.1 \pm 1.2$ & $17.3 \pm 6.1$ & $4.9 \pm 1.2$ \\
\hline & $\mathrm{OM} / \mathrm{OC}^{\mathrm{a}}$ & $1.92 \pm 0.04$ & $1.83 \pm 0.04$ & $2.00 \pm 0.06$ & $1.81 \pm 0.05$ \\
\hline & $\mathrm{O} / \mathrm{C}^{\mathrm{a}}$ & $0.59 \pm 0.03$ & $0.52 \pm 0.03$ & $0.65 \pm 0.04$ & $0.50 \pm 0.04$ \\
\hline \multirow{3}{*}{$n$-Alkanes $\left(\mathrm{ng} \mathrm{m}^{-3}\right.$ ) } & & $80 \pm 19$ & $19 \pm 5$ & $34 \pm 12$ & $10 \pm 4$ \\
\hline & $\mathrm{CPI}_{\text {odd }}$ & $2.0 \pm 0.3$ & $1.7 \pm 0.1$ & $1.7 \pm 0.1$ & $1.7 \pm 0.2$ \\
\hline & $\operatorname{Wax~C}_{n}(\%)$ & $35 \pm 5$ & $27 \pm 3$ & $28 \pm 4$ & $28 \pm 5$ \\
\hline \multirow[t]{6}{*}{ PAHs (ng m ${ }^{-3}$ ) } & & $18 \pm 12$ & $7 \pm 1$ & $9 \pm 9$ & $3 \pm 1$ \\
\hline & $\mathrm{BaP} /(\mathrm{BaP}+\mathrm{BeP})$ & $0.34 \pm 0.08$ & $0.37 \pm 0.03$ & $0.28 \pm 0.13$ & $0.32 \pm 0.04$ \\
\hline & IncdP / (IncdP + BghiP) & $0.59 \pm 0.06$ & $0.48 \pm 0.01$ & $0.61 \pm 0.04$ & $0.42 \pm 0.05$ \\
\hline & FLA / (FLA+PYR) & $0.55 \pm 0.01$ & $0.56 \pm 0.01$ & $0.60 \pm 0.02$ & $0.59 \pm 0.00$ \\
\hline & $\mathrm{BaA} /(\mathrm{BaA}+\mathrm{CHR})$ & $0.26 \pm 0.03$ & $0.28 \pm 0.03$ & $0.22 \pm 0.02$ & $0.22 \pm 0.03$ \\
\hline & $\mathrm{ANT} /(\mathrm{ANT}+\mathrm{PHE})$ & $0.09 \pm 0.01$ & $0.11 \pm 0.01$ & $0.06 \pm 0.02$ & $0.10 \pm 0.02$ \\
\hline \multirow[t]{3}{*}{ Monocarboxylic acids $\left(\mathrm{ng} \mathrm{m}^{-3}\right.$ ) } & & $363 \pm 58$ & $138 \pm 28$ & $166 \pm 49$ & $98 \pm 18$ \\
\hline & cis-Pinonic acid $\left(\mathrm{ng} \mathrm{m}^{-3}\right)$ & $5.3 \pm 1.7$ & $3.0 \pm 1.0$ & $4.4 \pm 1.6$ & $1.8 \pm 0.2$ \\
\hline & $\mathrm{C}_{18: 0} / \mathrm{C}_{18: 1}$ & $5.9 \pm 4.5$ & $7.2 \pm 3.1$ & $9.2 \pm 3.0$ & $11.1 \pm 2.9$ \\
\hline \multirow[t]{2}{*}{ Sugars $\left(\mathrm{ng} \mathrm{m}^{-3}\right)$} & & $248 \pm 21$ & $148 \pm 28$ & $109 \pm 43$ & $57 \pm 18$ \\
\hline & Levoglucosan $\left(\mathrm{ng} \mathrm{m}^{-3}\right)$ & $229 \pm 18$ & $136 \pm 23$ & $98 \pm 39$ & $52 \pm 15$ \\
\hline \multirow[t]{3}{*}{ Dicarboxylic acids $\left(\mathrm{ng} \mathrm{m}^{-3}\right)$} & & $522 \pm 137$ & $88 \pm 33$ & $355 \pm 151$ & $80 \pm 47$ \\
\hline & Dicarboxylic acids $\mathrm{C} / \mathrm{OC}$ & $0.038 \pm 0.009$ & $0.017 \pm 0.004$ & $0.041 \pm 0.006$ & $0.028 \pm 0.010$ \\
\hline & $\mathrm{O} / \mathrm{C}$ (dicarboxylic acids) & $0.90 \pm 0.02$ & $0.73 \pm 0.01$ & $0.92 \pm 0.05$ & $0.81 \pm 0.05$ \\
\hline
\end{tabular}

${ }^{a}$ Averages of daily OM / OC ratios and $\mathrm{O} / \mathrm{C}$ of total identified OM. ${ }^{\mathrm{b}}$ Averages of daily total OM estimated by measured OC and the OM / OC ratios of identified OM.

\subsubsection{Local and regional formation of $\mathrm{PM}_{2.5}$ during the haze period}

In the haze period, $\mathrm{PM}_{2.5} / \mathrm{PM}_{10}$ ratios in Seoul and Deokjeok are high $(\sim 0.8$; Table 1$)$, which shows a dominance of the anthropogenic fine-mode aerosols (Kim et al., 2007). The larger $\mathrm{PM}_{2.5} / \mathrm{PM}_{10}$ during the haze compared to the clean period in both places (Table 1) suggests more of an influence from secondary aerosol formation during the haze period (Irei et al., 2015).

The prolonged haze episode is characterized by a large proportion of secondary aerosols in $\mathrm{PM}_{2.5}$ (Fig. 4). The average fractions of secondary inorganic aerosol (SIA) species (sulfate, nitrate, and ammonium) in total $\mathrm{PM}_{2.5}$ mass during the haze period are $76 \%$ in Seoul and $65 \%$ in Deokjeok, while those during the clean period are reduced to $47 \%$ in Seoul and $51 \%$ in Deokjeok (Fig. 4 and Table 1). The sulfur oxidation ratio $\left(\mathrm{SOR}=n \mathrm{SO}_{4}^{2-} /\left[n \mathrm{SO}_{4}^{2-}+n \mathrm{SO}_{2}\right] ; n\right.$ refers to the molar concentration) represents the atmospheric conversion of $\mathrm{SO}_{2}$ to sulfate aerosol through oxidation and partitioning (Squizzato et al., 2013). The SOR is also higher during the haze period than during the clean period in Seoul (Table 1).
During the clean period, the SIA fraction in Seoul (47\%) is slightly smaller than that in Deokjeok (51\%) owing to the smaller sulfate fraction in Seoul $(18 \%)$ than in Deokjeok $(26 \%)$. During the haze period, on the other hand, the SIA fraction in Seoul (76\%) is much larger than in Deokjeok $(65 \%)$ mainly due to the larger nitrate fraction in Seoul $(28 \%)$ than in Deokjeok (13\%; Table 1). The large fraction of nitrate and the local emission of $\mathrm{NO}_{2}$ in Seoul indicate that a majority of nitrate aerosols is locally produced in the SMA. In addition, the large fraction of sulfate and dominant influences of regional transport on $\mathrm{SO}_{2}$ in Deokjeok indicate that sulfate aerosols are formed secondarily during longrange transport.

The high OC / EC (>7) during the haze period in both Seoul and Deokjeok (Table 1) indicates the large proportion of secondary organic aerosols (SOAs) in $\mathrm{PM}_{2.5}$ since EC is a representative primary constituent, while OC has both primary and secondary sources (Turpin and Huntzicker, 1995). Approximate primary OC (POC) and secondary OC (SOC) were obtained by a simple EC tracer method (Castro et al., 1999) using the minimum OC / EC values of 2.9 for Seoul and 2.2 for Deokjeok on 9 March as the primary OC / EC. As shown in Table 1, EC and thus POC concentrations in Seoul during both the haze and clean periods are higher than those 
Table 3. Comparisons of chemical and source characteristics of $\mathrm{PM}_{2.5}$ between Seoul and Deokjeok.

\begin{tabular}{|c|c|c|c|}
\hline Characteristics & Seoul (downwind urban) & Deokjeok (upwind background) & Components \\
\hline $\begin{array}{l}\text { Secondary inor- } \\
\text { ganic aerosols } \\
\text { (SIAs) }\end{array}$ & $\begin{array}{l}\text { Larger proportion of } \mathrm{PM}_{2.5} \text { during the haze } \\
\text { period due to higher } \mathrm{NO}_{3}^{-} / \mathrm{PM}_{2.5} \text { in Seoul } \\
\text { (local } \mathrm{NO}_{x} \text { emissions) }\end{array}$ & $\begin{array}{l}\text { Larger proportion of } \mathrm{PM}_{2.5} \text { during the clean } \\
\text { period due to higher } \mathrm{SO}_{4}^{2-} / \mathrm{PM}_{2.5} \text { in Deok- } \\
\text { jeok } \\
\text { (regional transport of } \mathrm{SO}_{2} \text { and } \mathrm{SO}_{4}^{2-} \text { ) }\end{array}$ & $\begin{array}{l}\mathrm{SIA} / \mathrm{PM}_{2.5} \\
\mathrm{NO}_{3}^{-} / \mathrm{PM}_{2.5} \\
\mathrm{SO}_{4}^{2-} / \mathrm{PM}_{2.5}\end{array}$ \\
\hline $\begin{array}{l}\text { Secondary or- } \\
\text { ganic aerosols } \\
\text { (SOAs) }\end{array}$ & Smaller fraction & Larger fraction & $\begin{array}{l}\text { OC / EC } \\
\text { Dicarboxylic acids } \\
\text { C/OC }\end{array}$ \\
\hline \multirow[t]{3}{*}{$\begin{array}{l}\text { Source charac- } \\
\text { teristics }\end{array}$} & $\begin{array}{l}\text { More biogenic VOCs and precursors } \\
\text { (urban forest) }\end{array}$ & $\begin{array}{l}\text { Less biogenic VOCs and precursors } \\
\text { (marine island) }\end{array}$ & $\begin{array}{l}\mathrm{CPI}_{\text {odd }} \\
\text { Wax } \mathrm{C}_{n} \\
\text { cis-Pinonic acid }\end{array}$ \\
\hline & $\begin{array}{l}\text { More biomass burning } \\
\text { (local and regional sources) }\end{array}$ & $\begin{array}{l}\text { Less biomass burning } \\
\text { (regional source) }\end{array}$ & Levoglucosan \\
\hline & $\begin{array}{l}\text { Grass, wood, and coal combustion sources } \\
\text { but more fossil fuel combustion }\end{array}$ & Grass, wood, and coal combustion sources & FLA / (FLA + PYR) \\
\hline
\end{tabular}

in Deokjeok, like CO. This shows that EC and POC in Seoul are largely contributed by local emissions, while those in Deokjeok are mostly influenced by regional transport. Although the OC concentration is higher in Seoul than in Deokjeok, its secondary fraction (SOC / OC) is higher in Deokjeok than in Seoul during both the haze and clean periods, probably due to secondary production during long-range transport to the background, as discussed in Sect. 3.3.

\subsection{Organic components in $\mathbf{P M}_{2.5}$}

In the present study, five organic compound groups ( $n$ alkanes, PAHs, monocarboxylic acids, sugars, and dicarboxylic acids) were found and analyzed. Various diagnostic ratios from these individual organic compounds are useful markers for the identification of primary anthropogenic and biogenic sources as well as secondary formation and aging of organic aerosols (OAs). To explore the oxidation and aging properties of $\mathrm{OA}$, atomic oxygen-to-carbon ratios $(\mathrm{O} / \mathrm{C})$ and organic-mass-to-carbon ratios (OM / OC) of SOA have been widely used (Aiken et al., 2008; Jimenez et al., 2009). The organic mass $(\mathrm{OM})$ identified in the current study is $\sim 5 \%$ of total OM estimated by the OM / OC of the identified OM. The average concentrations and diagnostic ratios of the organic compounds are presented in Table 2. Different source characteristics between Seoul and the upwind background and between the haze and clean periods derived from Table 2 are summarized and added in Tables 3 and 4 .

\subsubsection{Emission sources}

PAHs are combustion by-products of all types of organic matter, especially related to the incomplete combustion of fossil fuels and biomass burning (Nisbet and LaGoy, 1992; Bi et al., 2003). Various diagnostic ratios with individual PAH species are helpful in searching for their emission sources (Tobiszewski and Namieśnik, 2012). The average PAH ratios in Seoul and Deokjeok for the haze and clean 
Table 4. Comparisons of meteorological conditions and properties of $\mathrm{PM}_{2.5}$ between the haze and clean periods.

\begin{tabular}{|c|c|c|c|}
\hline Characteristics & Haze period (23-28 February) & Clean period (5-9 March) & Components \\
\hline $\begin{array}{l}\text { Meteorological } \\
\text { conditions }\end{array}$ & $\begin{array}{l}\text { Warm and humid } \\
\text { More stagnant (low winds) } \\
\text { Low boundary layer height }\end{array}$ & $\begin{array}{l}\text { Cold and dry } \\
\text { Less stagnant (high winds) } \\
\text { High boundary layer height }\end{array}$ & $\begin{array}{l}\text { Meteorological } \\
\text { factors in Seoul }\end{array}$ \\
\hline $\begin{array}{l}\text { Fine-mode } \\
\text { particles }\end{array}$ & Dominant $\left(>80 \%\right.$ of $\mathrm{PM}_{10}$ in Seoul) & Less dominant $\left(<60 \%\right.$ of $\mathrm{PM}_{10}$ in Seoul) & $\mathrm{PM}_{2.5} / \mathrm{PM}_{10}$ \\
\hline $\begin{array}{l}\text { Primary } \\
\text { aerosols }\end{array}$ & $\begin{array}{l}\text { Higher concentrations } \\
\text { (accumulation in the shallow boundary layer) }\end{array}$ & $\begin{array}{l}\text { Lower concentrations } \\
\text { (ventilation by high winds) }\end{array}$ & $\begin{array}{l}\text { EC } \\
n \text {-Alkanes, PAHs, } \\
\text { monocarboxylic } \\
\text { acids, sugars }\end{array}$ \\
\hline $\begin{array}{l}\text { Secondary } \\
\text { inorganic } \\
\text { aerosols } \\
\text { (SIAs) }\end{array}$ & $\begin{array}{l}\text { Larger proportion of } \mathrm{PM}_{2.5} \\
\left(\sim 76 \% \text { of } \mathrm{PM}_{2.5} \text { in Seoul }\right)\end{array}$ & $\begin{array}{l}\text { Smaller proportion of } \mathrm{PM}_{2.5} \\
\left(\sim 47 \% \text { of } \mathrm{PM}_{2.5} \text { in Seoul }\right)\end{array}$ & $\begin{array}{l}\mathrm{SIA} / \mathrm{PM}_{2.5} \\
\mathrm{NO}_{3}^{-} / \mathrm{PM}_{2.5} \\
\mathrm{SO}_{4}^{2-} / \mathrm{PM}_{2.5}\end{array}$ \\
\hline $\begin{array}{l}\text { Secondary } \\
\text { organic } \\
\text { aerosols } \\
\text { (SOAs) }\end{array}$ & $\begin{array}{l}\text { Larger fraction } \\
(\mathrm{OC} / \mathrm{EC} \sim 7.3 \text { in Seoul })\end{array}$ & $\begin{array}{l}\text { Smaller fraction } \\
(\mathrm{OC} / \mathrm{EC} \sim 3.7 \text { in Seoul })\end{array}$ & $\begin{array}{l}\text { OC / EC } \\
\text { Dicarboxylic acids } \\
\text { C / OC }\end{array}$ \\
\hline \multirow{2}{*}{$\begin{array}{l}\text { Aging, oxida- } \\
\text { tion, and pho- } \\
\text { tochemistry }\end{array}$} & More aged & Fresher & $\mathrm{BaP} /(\mathrm{BaP}+\mathrm{BeP})$ \\
\hline & $\begin{array}{l}\text { More oxidation } \\
\text { (warm and stagnant condition) } \\
\text { Enhanced photochemistry }\end{array}$ & $\begin{array}{l}\text { Less oxidation } \\
\text { (cold and ventilation effect) }\end{array}$ & $\begin{array}{l}\text { Dicarboxylic acids } \\
\text { O / C } \\
\text { SOR, O / C, } \\
\text { OM / OC } \\
\text { cis-Pinonic acid }\end{array}$ \\
\hline \multirow[t]{2}{*}{$\begin{array}{l}\text { Source char- } \\
\text { acteristics }\end{array}$} & Grass, wood, and coal combustion sources & Petroleum combustion sources & $\begin{array}{l}\text { IncdP / (IncdP + } \\
\text { BghiP) }\end{array}$ \\
\hline & Petrogenic (Deokjeok) & Pyrogenic & $\mathrm{ANT} /(\mathrm{ANT}+\mathrm{PHE}$ \\
\hline
\end{tabular}

periods are summarized in Fig. 5 with previously reported diagnostic ratios (Yunker et al., 2002; Pies et al., 2008; De La Torre-Roche et al., 2009; Akyüz and Çabuk, 2010; Oliveira et al., 2011). The interpretation of these PAH ratios all together seems ambiguous and contradictory due to the mixing of various emission sources. However, relative comparisons of each ratio between different places and different periods reveal more pyrogenic sources, such as fossil fuel combustion and vehicular emissions, in Seoul than in Deokjeok (Fig. 5a-c) in the overall influence of coal combustion and/or biomass burning during the haze period (Fig. 5a-b, and d).

Sugars mainly originate from biomass burning and numerous primary biological aerosols (Bi et al., 2008; Fu et al., 2012). Levoglucosan, which comprises more than $90 \%$ of the total sugar identified, is produced by the pyrolysis of cellulose and regarded as a representative marker for biomass burning (Simoneit et al., 1999). Similar to EC, the high levoglucosan concentration in Seoul, which is even higher than the haze-period levoglucosan levels in Deokjeok, implies that
Seoul is largely affected by local biomass burning together with regional transport.

$n$-Alkanes have biogenic sources, including particles shed from the epicuticular waxes of vascular plants, and anthropogenic sources, including fossil fuel and biomass combustion (Simoneit et al., 1991). Although the measurements in this study were conducted in the cold season, conifers that occupy $\sim 40 \%$ of the forest in South Korea (Lee et al., 2017) can be a biogenic source of organic compounds. Whereas short-chain (light) $n$-alkanes are mostly associated with incomplete combustion or vehicle exhaust (Gentner et al., 2017), biosynthetic processes result in long-chain high molecular weight $\left(\mathrm{C}_{27}-\mathrm{C}_{33}\right) n$-alkanes with a distinctive odd-to-even carbon number preference (Simoneit et al., 1991; Rogge et al., 1993). Note that $n$-alkanes in this study reflect fewer anthropogenic sources because we analyzed only high molecular weight $n$-alkanes $\left(\mathrm{C}_{20}-\mathrm{C}_{36}\right)$. The carbon preference index $\left(\mathrm{CPI}_{\mathrm{odd}}\right)$, defined by a concentration ratio of odd-to-even numbered $n$-alkane homologues, is higher than 3 for more biogenic sources and close to 1 for more anthro- 


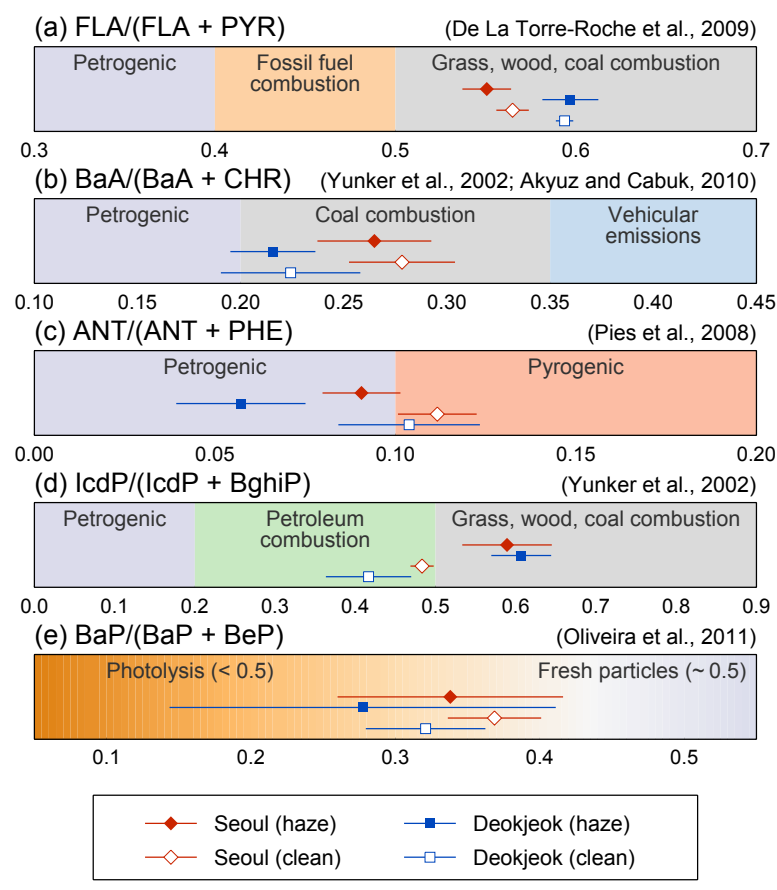

Figure 5. Various PAH ratios of (a) FLA / (FLA + PYR), (b) $\mathrm{BaA} /(\mathrm{BaA}+\mathrm{CHR}), \quad$ (c) $\mathrm{ANT} /(\mathrm{ANT}+\mathrm{PHE})$, (d) $\mathrm{IcdP} /(\mathrm{IcdP}+\mathrm{BghiP})$, and (e) $\mathrm{BaP} /(\mathrm{BaP}+\mathrm{BeP})$ in Seoul (red diamonds) and Deokjeok (blue squares) during the haze (solid symbols) and clean (open symbols) periods. The horizontal bars indicate standard deviation.

pogenic combustion sources (Simoneit, 1989). Together with the high percentage of plant wax $n$-alkanes (Wax $\mathrm{C}_{n}=\left[\mathrm{C}_{n}\right]$ $\left.-\left(\left[\mathrm{C}_{n+1}\right]+\left[\mathrm{C}_{n-1}\right]\right) / 2\right)$, the high $\mathrm{CPI}_{\text {odd }}$ in Seoul during the haze reflects more biogenic VOCs in Seoul from the urban forest. More biogenic emissions in Seoul than in Deokjeok are also supported by higher concentrations of cis-pinonic acid, which is a representative biogenic SOA species that originates from the $\mathrm{O}_{3}$ reactions of monoterpene (Zhang et al., 2010).

To sum up the above diagnostics, both Seoul and Deokjeok are commonly influenced by biomass burning and coal combustion sources. However, Seoul is more affected by fossil fuel combustion and vehicular emissions compared to Deokjeok and seems to also have local biomass burning and biogenic emission sources.

\subsubsection{Secondary formation and aging process}

The average OM / OC and O / C in Seoul were 1.92 and 0.59 for the haze period and 1.83 and 0.52 for the clean period (Table 2). Although these values may be overestimated because of the possible loss of semivolatile compounds arising from the measurement and analysis addressed in Sects. 2.1 and 2.2, the higher values of $\mathrm{OM} / \mathrm{OC}$ and $\mathrm{O} / \mathrm{C}$ during the haze indicate that $\mathrm{OA}$ was more oxygenated. Considering the higher OM / OC and OC in Deokjeok of 2.00 and 0.65 for the haze period (Table 2) together with the backward trajectories from China during the haze (Fig. 2), haze particles were already aged before arriving at Seoul and mixed with fresh compounds in Seoul.

Dicarboxylic acids could originate from primary sources, like fossil fuel combustion or biomass burning (Kawamura and Kaplan, 1987; Rogge et al., 1998), but this is more likely from secondary sources, like the gas-particle partitioning of semivolatile products from the photooxidation of anthropogenic or biogenic precursors and aqueous chemistry in aerosol waters (Rogge et al., 1993; Kundu et al., 2010; Zhang et al., 2010, 2016). In Table 2, the large proportions of dicarboxylic acid carbon in $\mathrm{OC}$ and the high dicarboxylic acids $\mathrm{O} / \mathrm{C}$ during the haze period support the idea that SOA has dominantly formed through oxidation in stagnant conditions. More dicarboxylic acids (carbon basis) in OC in Deokjeok than in Seoul is consistent with conclusions from the high SOC / OC in Deokjeok (Table 1) in Sect. 3.2.3. The OAs in the upwind background show more influence of aging and secondary production during long-range transport, while those in Seoul originate from a mixture of transported secondary sources and local primary sources.

The oxidation and aging of the aerosols could be further supported by diagnostic ratios of $\mathrm{PAH}$ isomers and $\mathrm{C}_{18}$ monocarboxylic acids. Benzo[ $a]$ pyrene $(\mathrm{BaP})$ is photodegraded more rapidly than its $\mathrm{PAH}$ isomer, benzo[e]pyrene (BeP), and thus $\mathrm{BaP} /(\mathrm{BaP}+\mathrm{BeP})$ is close to 0.5 for the fresh particles, while it is smaller than 0.5 for the aged particles (Oliveira et al., 2011; Tobiszewski and Namieśnik, 2012). The smaller $\mathrm{BaP} /(\mathrm{BaP}+\mathrm{BeP})$ during the haze compared to the clean period (Fig. 5e and Table 2) shows more aging processes during the long-lasting haze. Monocarboxylic acids (or fatty acids) originate from fossil fuel combustion, biomass burning, meat cooking, and biogenic sources, such as epicuticular plant waxes (Cheng et al., 2004; Choi et al., 2016). Among the monocarboxylic acids, the ratio of saturated stearic acid $\left(\mathrm{C}_{18: 0}\right)$ to unsaturated oleic and elaidic acids $\left(\mathrm{C}_{18: 1}\right)$ is higher for more aged aerosols because the unsaturated monocarboxylic acids are rapidly degraded to fragments via heterogeneous oxidation (Simoneit et al., 1991; Cheng et al., 2004). Higher $\mathrm{C}_{18: 0} / \mathrm{C}_{18: 1}$ with smaller $\mathrm{BaP} /(\mathrm{BaP}+\mathrm{BeP})$ in Deokjeok than in Seoul (Table 2) indicates that OAs in Seoul are fresher and that those in Deokjeok are more aged.

\subsection{Temporal evolution of the multiday haze}

Figures 6 and 7 show the temporal evolution of the concentrations of SIA species and their precursor gases, carbonaceous aerosol components and $\mathrm{CO}$, and the five individual organic compound groups measured at both the Seoul and Deokjeok sites together with the meteorological factors in Seoul. Correlations between meteorological parameters and chemical components in Seoul are listed in Table 5 to help 
(a) $\mathrm{SO}_{2}$ and nss- $\mathrm{SO}_{4}{ }^{2}$

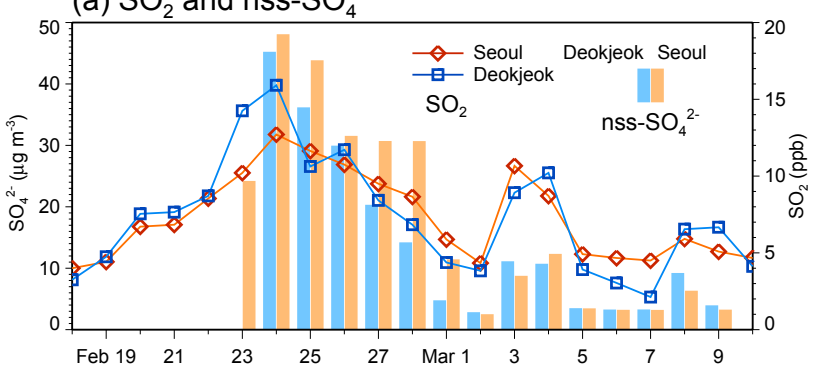

(c) $\mathrm{NO}_{2}$ and $\mathrm{NO}_{3}^{-}$

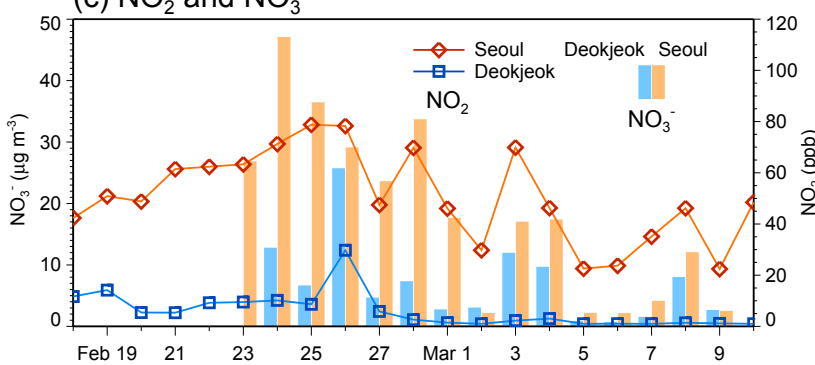

(e) Temperature and specific humidity

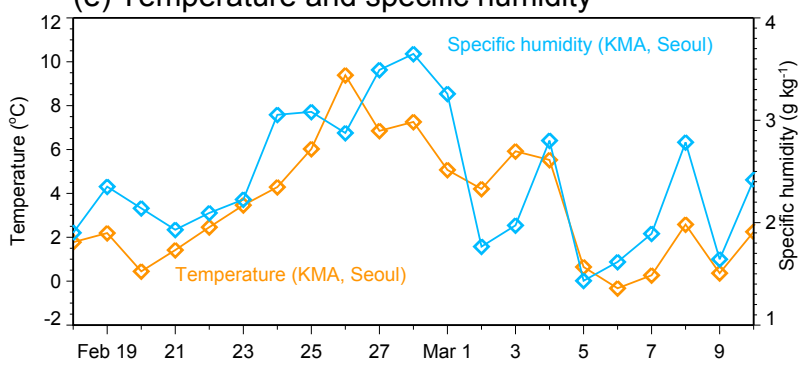

(b) SOR

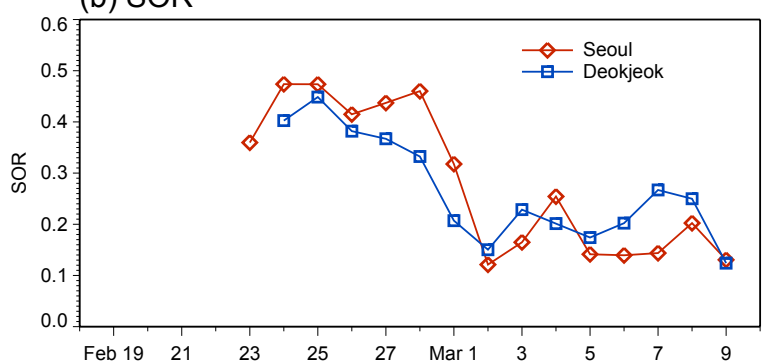

(d) EC and $\mathrm{CO}$

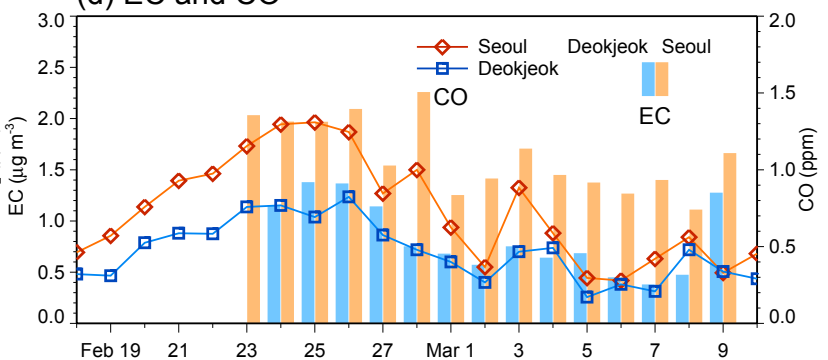

(f) Wind speed and boundary layer height

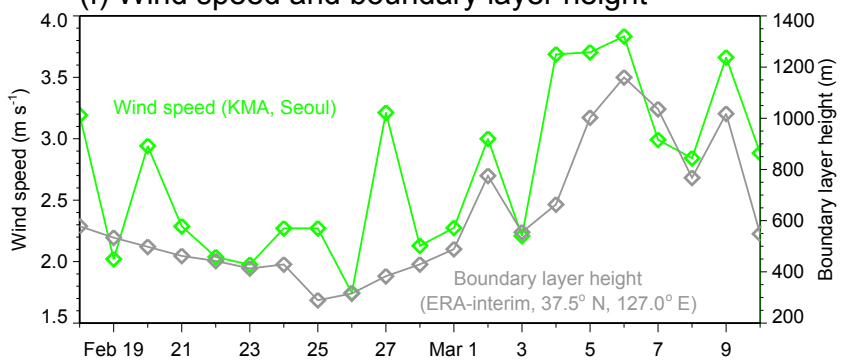

Figure 6. Daily time series of gas-phase pollutants $\left(\mathrm{SO}_{2}, \mathrm{NO}_{2}, \mathrm{CO}\right)$, secondary inorganic aerosol compounds (nss- $\mathrm{SO}_{4}^{2-}$ and $\left.\mathrm{NO}_{3}^{-}\right)$and SOR, carbonaceous species (EC and OC), and meteorological factors (temperature, specific humidity, wind speed, and boundary layer height) during the analysis period.

understand the role of meteorological factors in the temporal variation in each component.

Sulfate profiles (Fig. 6a) roughly follow the trend of $\mathrm{PM}_{2.5}$ concentrations as higher in Seoul than in Deokjeok (Fig. 1b). A rapid increase in sulfate concentrations between 23 and 24 February in Seoul indicates the introduction of sulfate by regional transport. Similar concentrations of sulfate in Seoul and Deokjeok peaking on 24 February and decaying afterwards confirm a strong impact of regional transport on sulfate in the early stage of the haze. A sharp increase in specific humidity on 24 February shows abrupt changes in air mass property and thus source origin (Fig. 6e). The sulfate concentrations in Deokjeok gradually decreased between 25 and 28 February, while those in Seoul stayed at $30 \mu \mathrm{g} \mathrm{m}^{-3}$. Thus, the prolonged high sulfate level in Seoul must be affected by local production. Increasing SOR in Seoul despite the decreasing SOR in Deokjeok between 26 and 28 February supports growing local sulfate formation in Seoul during the late stage of the multiday haze (Fig. 6b). Along with the stable and stagnant environment, the warm and humid air conditions during the haze period (Fig. 6e) could also be conducive to both the gas-phase and aqueous-phase oxidation of $\mathrm{SO}_{2}$ (Liang and Jacobson, 1999; Seinfeld and Pandis, 2006). SOR shows significant correlations with temperature $(r=0.72)$ or RH $(r=0.59)$ and wind speed $(r=-0.64)$ and BLH $(r=-0.88)$. Interestingly, the correlation of sulfate with temperature $(r=0.64)$ or $\mathrm{RH}(r=0.47)$ is weaker than with SOR due to the transport of external sulfate into Seoul during the early stage of the haze.

As illustrated in the previous section, both $\mathrm{NO}_{2}$ and nitrate profiles show much higher concentrations in Seoul than in Deokjeok owing to large $\mathrm{NO}_{x}$ emissions in Seoul (Fig. 6c). The high dependence of $\mathrm{NO}_{2}$ and nitrate on the boundary layer and winds (Table 5) in Seoul reflects significant influences of such meteorological factors on the species originating from local primary emissions and secondary production. For example, the $\mathrm{NO}_{2}$ concentration in Seoul gradually increased with lowering BLH until 25 February and then 
Table 5. Correlation coefficients between meteorological variables and each component in Seoul for the measurement period of 23 February to 9 March 2014.

\begin{tabular}{|c|c|c|c|c|}
\hline & Temperature & $\begin{array}{l}\text { Relative } \\
\text { humidity }\end{array}$ & $\begin{array}{l}\text { Wind } \\
\text { speed }\end{array}$ & $\begin{array}{l}\text { Boundary } \\
\text { layer height }\end{array}$ \\
\hline $\mathrm{PM}_{2.5}$ & $+0.68^{\mathrm{c}}$ & +0.49 & $-0.70^{\mathrm{c}}$ & $-0.89^{\mathrm{c}}$ \\
\hline $\mathrm{SO}_{4}^{2-}$ & $+0.64^{\mathrm{b}}$ & +0.47 & $-0.61^{\mathrm{c}}$ & $-0.82^{\mathrm{c}}$ \\
\hline $\mathrm{NO}_{3}^{-}$ & $+0.68^{\mathrm{c}}$ & $+0.53^{\mathrm{b}}$ & $-0.71^{\mathrm{c}}$ & $-0.87^{\mathrm{c}}$ \\
\hline $\mathrm{NH}_{4}^{+}$ & $+0.66^{\mathrm{c}}$ & +0.50 & $-0.67^{\mathrm{c}}$ & $-0.86^{\mathrm{c}}$ \\
\hline $\mathrm{EC}^{4}$ & $+0.57^{\mathrm{b}}$ & +0.03 & $-0.66^{\mathrm{c}}$ & $-0.65^{\mathrm{c}}$ \\
\hline $\mathrm{OC}$ & $+0.65^{\mathrm{c}}$ & +0.33 & $-0.79^{c}$ & $-0.89^{c}$ \\
\hline $\mathrm{OM}^{\mathrm{a}}$ & $+0.62^{b}$ & +0.34 & $-0.75^{\mathrm{c}}$ & $-0.86^{\mathrm{c}}$ \\
\hline$n$-alkanes ${ }^{\mathrm{a}}$ & $+0.81^{\mathrm{c}}$ & +0.38 & $-0.79^{c}$ & $-0.89^{\mathrm{c}}$ \\
\hline $\mathrm{PAHs}^{\mathrm{a}}$ & +0.32 & +0.33 & -0.45 & -0.50 \\
\hline Monocarboxylic acids ${ }^{\mathrm{a}}$ & $+0.81^{\mathrm{c}}$ & +0.25 & $-0.87^{\mathrm{c}}$ & $-0.92^{\mathrm{c}}$ \\
\hline Sugars $^{\mathrm{a}}$ & $+0.62^{\mathrm{b}}$ & +0.26 & $-0.71^{\mathrm{c}}$ & $-0.81^{\mathrm{c}}$ \\
\hline Dicarboxylic acids ${ }^{\mathrm{a}}$ & $+0.62^{\mathrm{b}}$ & +0.53 & $-0.63^{b}$ & $-0.83^{\mathrm{c}}$ \\
\hline SOR & $+0.72^{\mathrm{c}}$ & $+0.59^{\mathrm{b}}$ & $-0.64^{b}$ & $-0.88^{c}$ \\
\hline $\mathrm{OC} / \mathrm{EC}$ & $+0.65^{\mathrm{c}}$ & $+0.51^{\mathrm{b}}$ & $-0.72^{\mathrm{c}}$ & $-0.90^{\mathrm{c}}$ \\
\hline 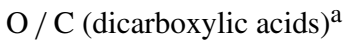 & $+0.71^{\mathrm{c}}$ & $+0.54^{\mathrm{b}}$ & $-0.60^{\mathrm{b}}$ & $-0.87^{\mathrm{c}}$ \\
\hline $\mathrm{O} / \mathrm{C}(\text { total identified } \mathrm{OM})^{\mathrm{a}}$ & +0.16 & +0.52 & -0.06 & -0.37 \\
\hline $\mathrm{OM} / \mathrm{OC}^{\mathrm{a}}$ & +0.14 & +0.51 & -0.05 & -0.35 \\
\hline
\end{tabular}

a Data for organic compounds on 25 February are not available. ${ }^{b}$ Statistically significant at $95 \%$ confidence level. ${ }^{\mathrm{c}}$ Statistically significant at $99 \%$ confidence level.

started to decrease on 26 February with rising BLH (Fig. 6f). The high wind speeds on 27 February and 2 March correspond to the low concentration peaks of $\mathrm{NO}_{2}$ and nitrate on the same days. In addition, the high $\mathrm{NO}_{2}$ and nitrate concentrations in Deokjeok on 26 February must be affected by transport from the SMA since the easterly winds were observed only on that day as mentioned in Sect. 3.1. The high correlation of RH with nitrate $(r=0.53$; Table 5) implies a role of aqueous chemistry in nitrate aerosol formation in Seoul. A recent thermodynamic model simulation with smog chamber experiments and measurement data (Lim et al., 2017) reveals that $\mathrm{NO}_{x}$ photochemistry under high RH conditions facilitates the hygroscopic growth of aerosols through water and $\mathrm{HNO}_{3}$ uptake cycles with organonitrate formation in aerosol liquid water (Lim et al., 2016) and thus contributes to the high nitrate proportion to $\mathrm{PM}_{2.5}$ in Seoul (Fig. 4a).

The temporal evolution of $\mathrm{CO}$ shows mixed characteristics of $\mathrm{SO}_{2}$ and $\mathrm{NO}_{2}$ profiles (Fig. 6d). Like $\mathrm{SO}_{2}$ concentrations, $\mathrm{CO}$ levels gradually increased in both Seoul and Deokjeok in the early stage of the haze, and this shows continuous regional influences during the haze period. On the other hand, the concentration differences in CO between Seoul and Deokjeok are large during the haze period but small on the high wind speed days (e.g., 27 February and 2 March) like $\mathrm{NO}_{2}$ concentrations. This indicates a local influence on the high CO levels in Seoul. EC generally shows similar temporal variation as $\mathrm{CO}$ (Fig. 6d) that is highly negatively correlated with wind speed and BLH (Table 5).
Although the high $\mathrm{O} / \mathrm{C}$ and $\mathrm{OM} / \mathrm{OC}$ of the estimated $\mathrm{OM}$ in both Seoul and Deokjeok imply the predominance of SOA, the overall time variation in OM (Fig. 7a) is similar to $\mathrm{CO}$ (Fig. 6d), which shows both local and regional influences. The mixed characteristics of local emissions of primary OM and SOA precursor gases in Seoul, the regional transport of primary and secondary OA in Deokjeok, and more SOA formation during the haze dissolve in the temporal evolution of OM.

$n$-Alkanes, PAHs, monocarboxylic acids, and sugars commonly show high concentrations in Seoul during the haze period, low concentration peaks on high wind days (27 February and 2 March), and high concentration peaks in Deokjeok on the easterly wind day (26 February; Fig. 7b-e). These are the local characteristics as shown in $\mathrm{NO}_{2}$. Higher concentrations of $n$-alkanes, monocarboxylic acids, and sugars during the haze period than during the clean period in Deokjeok show the regional transport characteristics as shown in $\mathrm{SO}_{2}$. PAHs in Deokjeok show low concentrations with small temporal variability, except for high concentration peaks on 26 February associated with transport from the SMA by easterly winds (Fig. 7c). This clearly indicates the local influence of primary organic compounds on the high OM concentrations in Seoul during the prolonged haze, as also shown by the higher proportion of POC in OC and the higher concentration of POC in Seoul $\left(5.7 \mu \mathrm{g} \mathrm{m}^{-3}, 40 \%\right.$ of OC) compared with Deokjeok $\left(2.5 \mu \mathrm{g} \mathrm{m}^{-3}, 31 \%\right.$ of OC; Table 1$)$.

As briefly mentioned in Sect. 3.3, dicarboxylic acids mainly originate from secondary sources. Concentration dif- 
(a) Total and identified OM

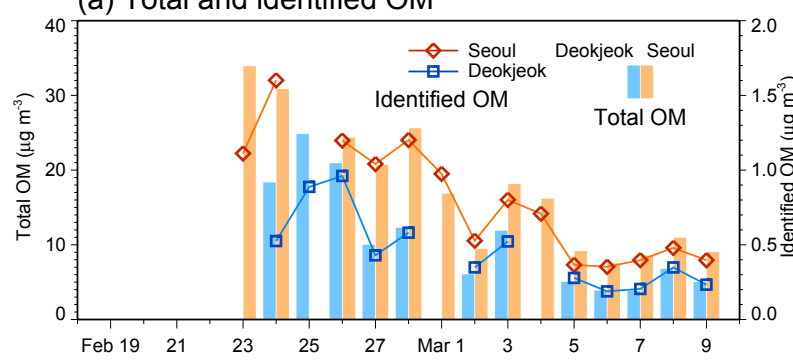

(c) PAHs

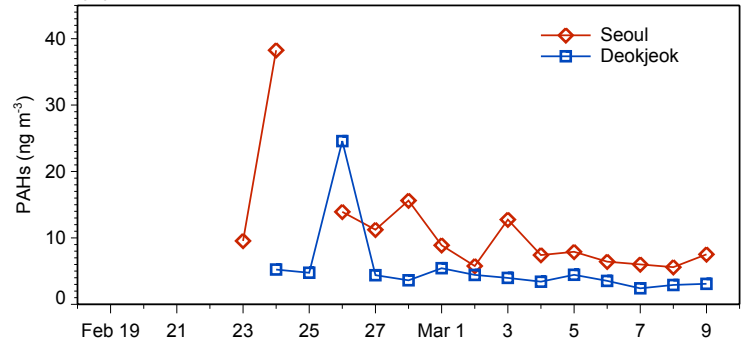

(e) Sugars

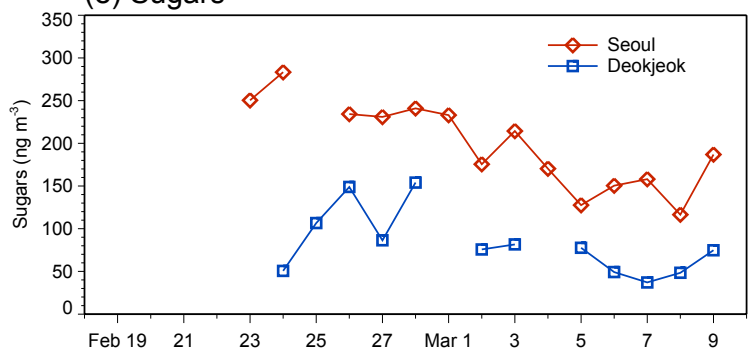

(g) $\mathrm{O} / \mathrm{C}$ ratios (dicarboxylic acids)

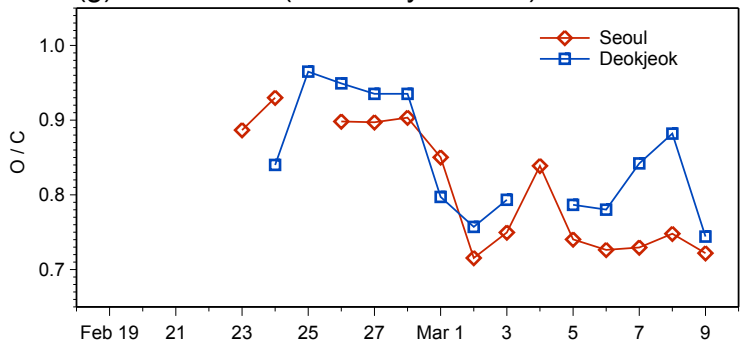

(b) Alkanes

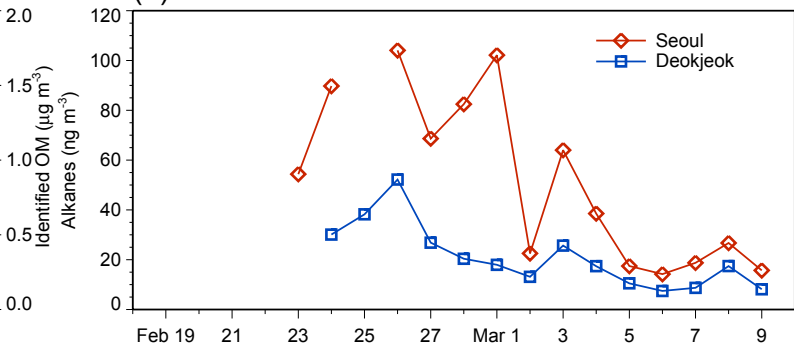

(d) Monocarboxylic acids

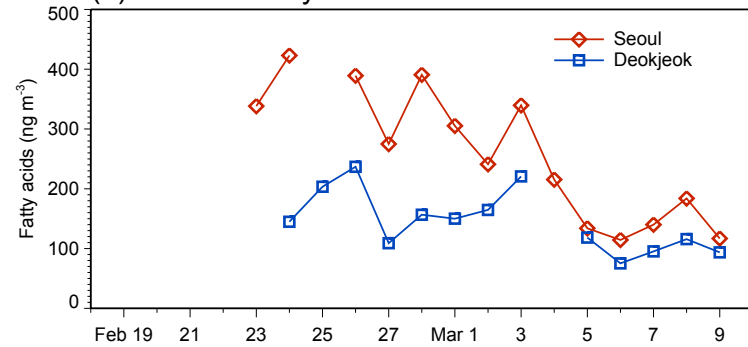

(f) Dicarboxylic acids

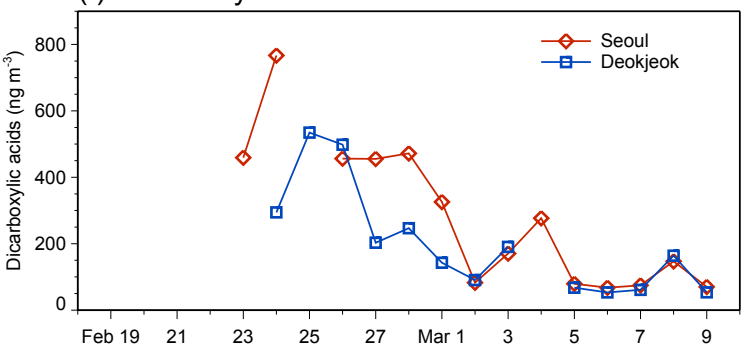

(h) $\mathrm{O} / \mathrm{C}$ ratios (total identified OM)

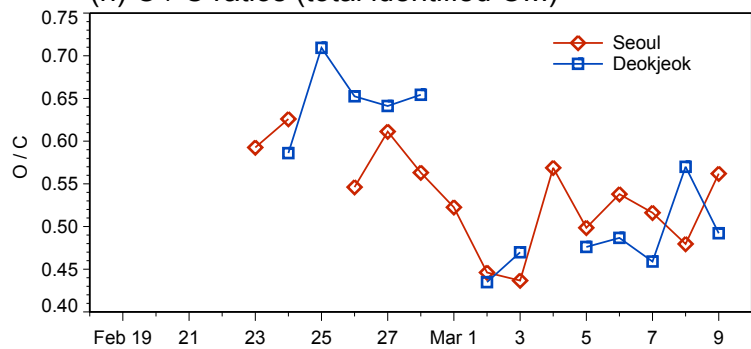

Figure 7. Daily time-series of (a) total identified OM and estimated total OM, (b) $n$-alkanes, (c) polycyclic aromatic hydrocarbons (PAHs), (d) monocarboxylic acids, (e) sugars, (f) dicarboxylic acids, (g) O / C of the dicarboxylic acids, and (h) $\mathrm{O} / \mathrm{C}$ of the total identified OM at the KIST site in Seoul and the Deokjeok site for the analysis period.

ferences in dicarboxylic acids between Seoul and Deokjeok are small during the clean period, but they are large during the haze period (except on 26 February), probably due to influences of local precursor emissions and secondary formation in Seoul (Fig. 7f). On the other hand, high concentrations of dicarboxylic acids in Deokjeok during the early stage of the prolonged haze must be due to the regional transport of pre-formed products (Fig. 7f). The $\mathrm{O} / \mathrm{C}$ of both dicarboxylic acids and total identified OM stayed high during both the early and late stages of the haze period in both places; this in- dicates secondary production as a source of the organic compounds during the long-lasting haze (Fig. $7 \mathrm{~g}$ and $\mathrm{h}$ ). To sum up, the high concentration of dicarboxylic acids in Seoul during the multiday haze is a combined result of local emissions, secondary formation, and early-stage regional transport.

It should be noted that significant correlations with $\mathrm{RH}$ were also found for dicarboxylic acids $\mathrm{O} / \mathrm{C}(r=0.54)$ and OC / EC ( $r=0.51$; Table 5). The stronger and more significant correlation of RH with OC / EC than with the OC concentration $(r=0.33)$ suggests probable aqueous-phase pro- 
cesses for SOA formation during the prolonged haze. This is also supported by the much stronger correlations of RH with dicarboxylic acids $(r=0.53)$ and dicarboxylic acids $\mathrm{O} / \mathrm{C}(r=0.54)$ than with other primary organic compounds $(0.25<r<0.38$; Table 5$)$. The hygroscopicity of OA can be enhanced with increasing $\mathrm{O} / \mathrm{C}$ and $\mathrm{OM} / \mathrm{OC}$ by SOA production and aging (Aiken et al., 2008; Jimenez et al., 2009). The higher correlations of RH with the $\mathrm{O} / \mathrm{C}$ of total identified OM $(r=0.54)$ and $\mathrm{OM} / \mathrm{OC}(r=0.51)$ compared to other meteorological variables implies hygroscopic properties of SOA produced during the long-lasting haze in Seoul.

\subsection{Role of synoptic conditions in the multiday haze}

Local meteorological factors, which play an important role in the accumulation of both primary pollutants and secondary aerosol precursors as well as secondary formation processes, are largely controlled by synoptic-scale conditions (Zheng et al., 2015). In addition, some specific distributions of highand low-pressure systems could provide a favorable pathway to transport external pollutants (Lee et al., 2011; Oh et al., 2015). We examined the influence of synoptic conditions on the day-to-day variation in meteorological factors and the temporal evolution of the multiday haze using geopotential height and wind fields at $850 \mathrm{hPa}$ (about $1.5 \mathrm{~km}$ of altitude) together with AOD.

From 19 to 21 February, a migratory anticyclone developed over southern China and moved eastward from the Sichuan Basin to the Yangtze River Delta, and high AOD was observed in the North China Plain (Fig. 8). As the highpressure system moved eastward, a clockwise circulation transported aerosols that had accumulated in the stable and stagnant air mass into North China, resulting in the rapidly rising $\mathrm{PM}_{2.5}$ concentrations in this region (Fig. 1c). This high-pressure system slowed down and stayed over the East China Sea between 22 and 24 February. During the period, the Korean Peninsula was under the direct influence of the slow anticyclonic circulation along the northwestern flank of the stagnant high-pressure system. The anticyclonic flow induced warm and humid advection along the eastern coast of China and accumulated and produced primary and secondary aerosols over North China and the Yellow Sea, as shown by the high AOD values over the regions. Backward trajectories passing through these regions indicate a dominant influence of regional transport on the nationwide increase in PM concentrations in South Korea in the early stage of the prolonged haze (Figs. 1b, 2a, and 3b-d).

As a trough developed over southern China on 25 February, the northwestern flank of the anticyclone was elongated and stretched toward the Korean Peninsula. This pattern provided a stable condition over South Korea, but it also caused weak transport from the west. The anticyclone started to move eastward again on 26 February, and the following low-pressure system resulted in easterly winds in the SMA. The easterly winds induced a warm peak of temper- ature and a slightly decreasing peak of specific humidity in Seoul (Fig. 6e) associated with foehn-related phenomena caused by a north-south mountain range in the east of the Korean Peninsula. Staggered backward trajectories over and near the Korean Peninsula until 1 March imply a dominant role of local emissions and production in the late stage of the haze episode. The synoptic conditions between 2 and 3 March resemble those between 20 and 25 February; however, the high-pressure system was located slightly northward and quickly moved eastward. Aerosols were therefore less accumulated over North China (Fig. 1c) and quickly passed through the Korean Peninsula between 3 and 4 March (Fig. 1b). The high concentrations of $\mathrm{SO}_{2}$, sulfate, nitrate, $\mathrm{CO}$, and $\mathrm{OM}$ in both Seoul and Deokjeok on these 2 days (Figs. 6a, 6c-d, and 7a) indicate the quick transport of $\mathrm{PM}_{2.5}$ components from China.

The haze-related high-pressure system, which slowly developed over China and moved into the Korean Peninsula, is analogous to the composite anomaly pattern at $850 \mathrm{hPa}$ of geopotential height for the multiday high $\mathrm{PM}_{10}$ episodes in Seoul reported by Oh et al. (2015). However, as shown by the difference between two subcases (20 February to 1 March and 3-4 March), the duration of the haze episodes and their sources (regional or local) also depend on the zonal speed of the synoptic-scale systems. One key weather pattern to hinder the eastward advance of weather systems in the midlatitudes is atmospheric blocking, which usually has a dipole structure of an equatorward cyclone and a poleward anticyclone or an omega-shaped ridge (Pelly and Hoskins, 2003; Tyrlis and Hoskins, 2008). In the geopotential height fields at $500 \mathrm{hPa}$ (about $5.5 \mathrm{~km}$ of altitude), a planetary wave ridge appeared over the Gulf of Alaska on 21 February (Fig. 9). The ridge developed into the omega-shaped blocking over Alaska (24 February to $1 \mathrm{March}$ ) and was responsible for the stagnant synoptic-scale weather systems during the period by interrupting zonal circulation. In contrast, the zonal propagation of synoptic disturbances became fast after the dissipation of the blocking anticyclone (2-5 March). As a result, the fast-moving high-pressure system and following low-pressure system induced the quick transport of external pollutants but less accumulation of domestic pollutants in South Korea on 3-4 March.

\section{Conclusions}

The evolution of the multiday haze in late February 2014 in the highly industrialized region located downwind of the Asian continental outflow has been investigated by $\mathrm{PM}_{2.5}$ chemical speciation in Seoul and its upwind background, Deokjeok Island, over the Yellow Sea. $\mathrm{PM}_{2.5}$ in Seoul was different than in Deokjeok, showing higher concentrations of primary aerosols, a larger nitrate fraction, more biogenic VOCs and precursors, and more pyrogenic sources, including fossil fuel combustion and biomass burning, but smaller 

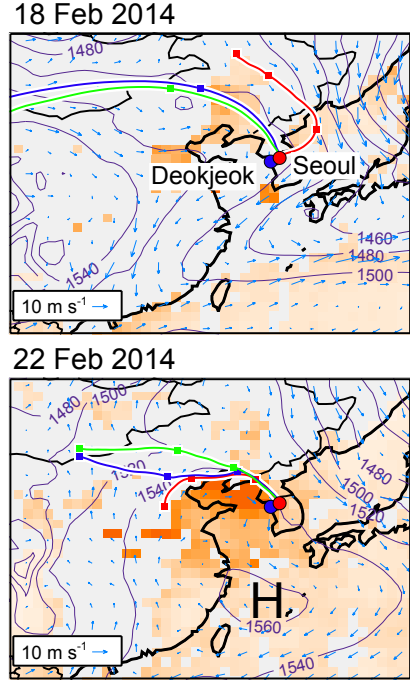

26 Feb 2014

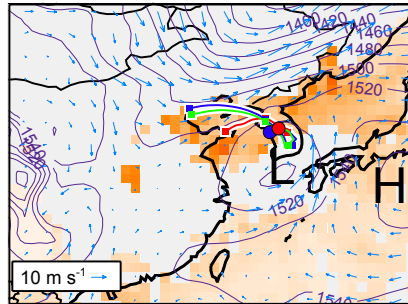

2 Mar 2014

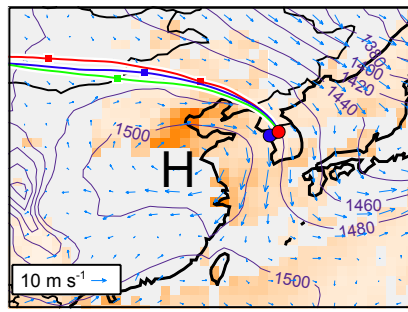

19 Feb 2014

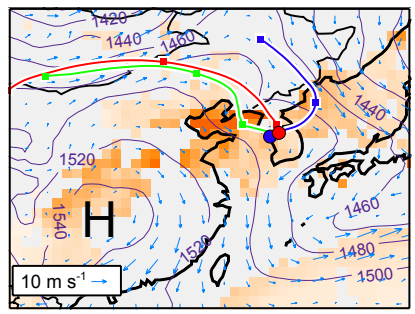

23 Feb 2014

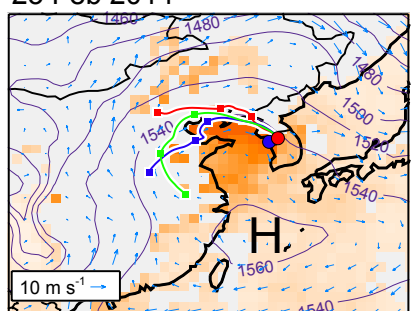

27 Feb 2014

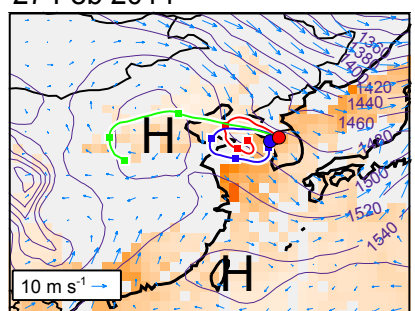

3 Mar 2014

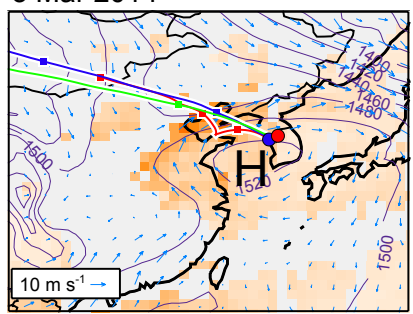

20 Feb 2014

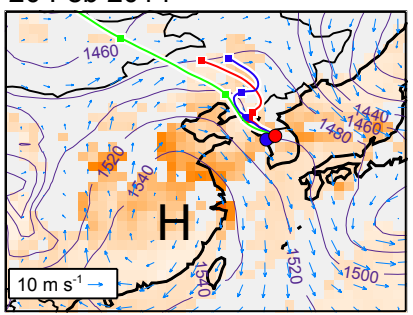

24 Feb 2014

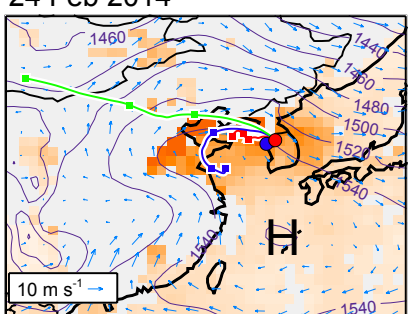

28 Feb 2014

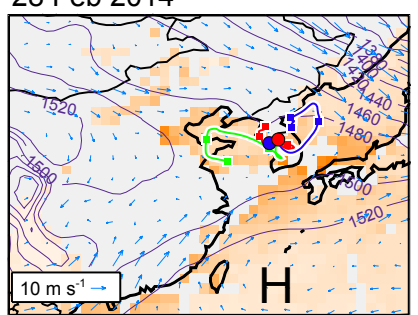

4 Mar 2014

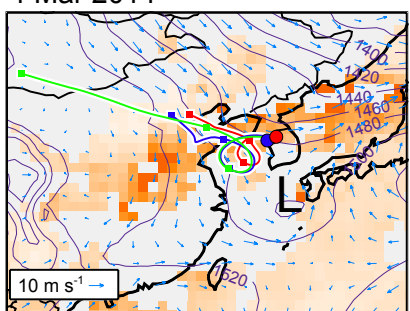

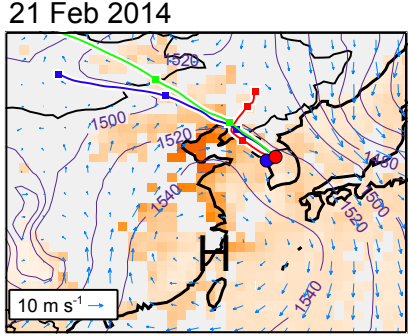

25 Feb 2014

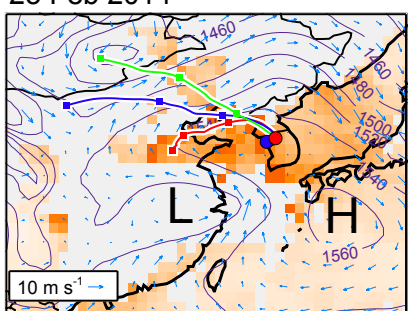

1 Mar 2014

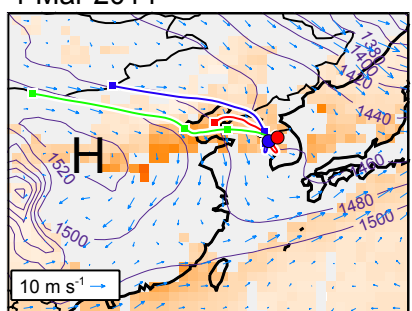

5 Mar 2014

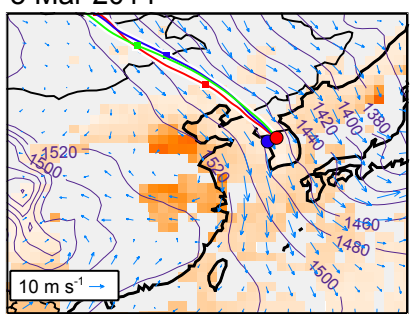

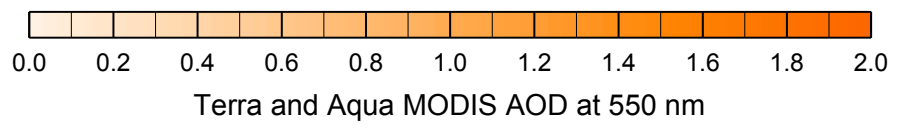

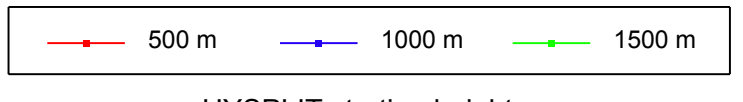

HYSPLIT starting height

Figure 8. Daily evolution of synoptic meteorological conditions over East Asia during the multiday haze episode in 2014. ERA-Interim daily mean geopotential height (contours; unit of gpm) and wind (arrows) at $850 \mathrm{hPa}$ are superimposed on the Terra and Aqua MODIS AOD at $550 \mathrm{~nm}$. The red, blue, and green lines with squares respectively represent backward trajectories from $500 \mathrm{~m}, 1000 \mathrm{~m}$, and $1500 \mathrm{~m}$ a.s. 1 . over the sampling site at 21:00 local time (GMT+09:00) on each day with endpoints at a $24 \mathrm{~h}$ interval.

sulfate and less-oxidized SOA fractions. Such differences reflect the fact that $\mathrm{PM}_{2.5}$ in Seoul was affected by both local and regional sources, while that in Deokjeok was affected by regional transport.

During the haze period, the $\mathrm{PM}_{2.5}$ level in Seoul was largely increased by primary and secondary aerosols. In particular, SIA species occupied $76 \%$ of the total $\mathrm{PM}_{2.5}$ mass, OC / EC reached 7.29, and O / C and OM / OC were about 0.6 and 1.9, respectively. The increase in primary and secondary aerosols is closely related to the warm, humid, and stagnant meteorological conditions during the haze period, which are conducive to the accumulation of pollutants and the oxidation of precursors. The higher correlations of RH with nitrate, SOR, OC / EC, dicarboxylic acids, O/C, and $\mathrm{OM} / \mathrm{OC}(r>0.5)$ compared to those with $\mathrm{EC}$ or other primary organic compounds $(r<0.4)$ show the role of aqueous processes in the oxidation and formation of secondary aerosol species.

The temporal evolution of the $\mathrm{PM}_{2.5}$ chemical components in both places shows a sequential influence of regional and 
18 Feb 2014

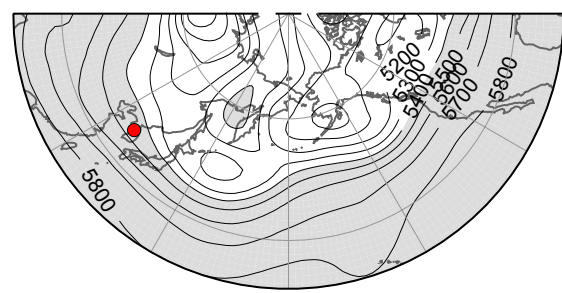

27 Feb 2014

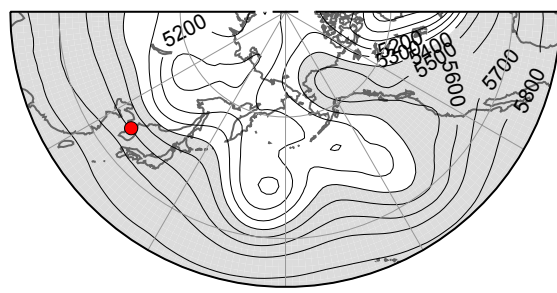

21 Feb 2014

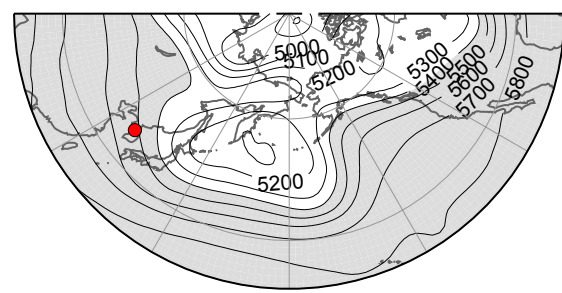

2 Mar 2014

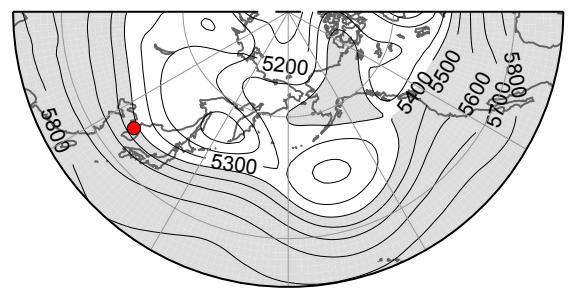

24 Feb 2014

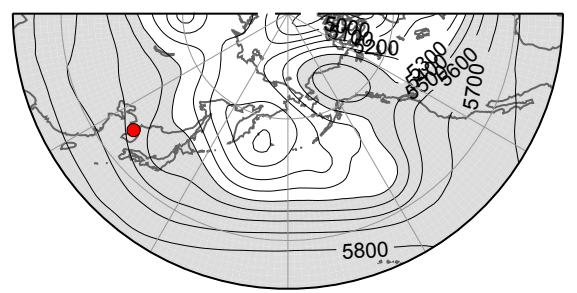

5 Mar 2014

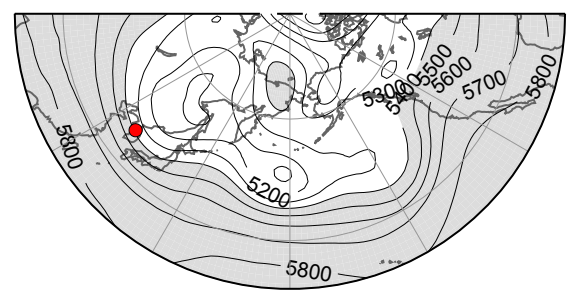

Figure 9. ERA-Interim daily mean geopotential height (contours; unit of gpm) at $500 \mathrm{hPa}$. Seoul is marked with a solid red circle, and the areas for which the geopotential height is higher than $5400 \mathrm{gpm}$ are shaded.

local sources on the prolonged haze period. High concentrations of sulfate in both Seoul and Deokjeok in the early stage of the haze episode indicate a significant regional influence on the high sulfate fraction in Seoul (30\%), especially at the onset of the multiday haze. On the other hand, a much higher concentration of nitrate in Seoul $\left(28 \%\right.$ of $\left.\mathrm{PM}_{2.5}\right)$ than in Deokjeok for the overall episode shows local formation and accumulation under the influence of a low BLH. Concentrations of organic compounds show similar behavior to the nitrate concentration. Stagnant atmospheric conditions extended the haze period by local contributions.

The transboundary transport of external pollutants and day-to-day variation in the local meteorological factors are controlled by synoptic-scale conditions. A migratory anticyclone in southern China accumulated aerosols over the North China Plain and the Yellow Sea. As the high-pressure system slowly moved eastward, weak anticyclonic flow transported the accumulated aerosols into the Korean Peninsula in the early stage of the multiday haze. In the middle and late stages, the eastward-moving high-pressure system governed the Korean Peninsula and provided favorable meteorological conditions for the accumulation and secondary formation of aerosols. The duration of the haze depends on the zonal propagation speed of the synoptic-scale systems. During the longlasting haze period, a blocking ridge developed over Alaska hindering zonal flows, and the eastward migration of the anticyclone slowed down over the East China Sea.

Our findings show the important role of synoptic conditions in the onset and evolution of the multiday haze in the downwind region of East Asia with explicit chemical details of haze development sequentially by regional transport and local sources. Since most of the megacities in the populated and industrialized region act as both importers and exporters of air pollutants, their air quality must be affected by both regional and local emission sources. As a synoptic system conducive to the accumulation of air pollutants and the production of secondary aerosols moves from the upwind region, the air quality in the downwind region is affected not only by the transport of air pollutants from the upwind area but also by the propagation of such a conducive weather system itself. Although the multiday high PM episode started with the transport of external pollutants, the local emission of primary pollutants and secondary precursors and the secondary formation of particles in the downwind region under certain meteorological conditions exacerbates air quality and prolongs the haze period. For instance, the high PM concentration in Deokjeok, where the local emissions are negligible, decreased 2-3 days earlier than in Seoul in the multiday haze episode in this study. The duration of the pollution episode also depends on the zonal propagation speed of such a hazefavorable weather system, and the atmospheric blocking pattern particularly prolongs the haze period.

Data availability. The raw $\mathrm{PM}_{2.5}$ and $\mathrm{PM}_{10}$ data that are measured and analyzed in this study are archived at the KIST and are available on request. The hourly data of $\mathrm{PM}_{10}, \mathrm{SO}_{2}, \mathrm{NO}_{2}, \mathrm{CO}$, and $\mathrm{O}_{3}$ concentrations can be found on the website managed by the Korea Environment Corporation (https://www.airkorea.or.kr). The hourly data of temperature, RH, and wind speed are available on the website of the KMA (http://www.kma.go.kr). The ERA-Interim data can be accessed via the European Centre for Medium-Range Weather Forecasts (ECMWF) data server (http://apps.ecmwf.int/datasets/). The MODIS AOD data can be obtained from the NASA Giovanni portal (https://giovanni.gsfc.nasa.gov/giovanni/). 


\section{The Supplement related to this article is available online at https://doi.org/10.5194/acp-17-9311-2017-supplement.}

Competing interests. The authors declare that they have no conflict of interest.

Acknowledgements. This work was supported by the Korea Institute of Science and Technology (KIST) and the National Research Foundation of Korea, grant NRF-2011-0028597. Yong Bin Lim acknowledges support from the Brain Pool Fellowship by the Ministry of Science, ICT and Future Planning, South Korea (152S-5-2-1416). The authors are grateful to the editor and two anonymous referees for their valuable and constructive comments.

Edited by: Barbara Ervens

Reviewed by: two anonymous referees

\section{References}

Aggarwal, S. G., Kumar, S., Mandal, P., Sarangi, B., Singh, K., Pokhariyal, J., Mishra, S. K., Agarwal, S., Sinha, D., Singh, S., Sharma, C., and Gupta, P. K.: Traceability issue in $\mathrm{PM}_{2.5}$ and $\mathrm{PM}_{10}$ measurements, Mapan-J. Metrol. Soc. I., 28, 153-166, https://doi.org/10.1007/s12647-013-0073-x, 2013.

Ahmed, E., Kim, K.-H., Shon, Z.-H., and Song S.-K.: Longterm trend of airborne particulate matter in Seoul, Korea from 2004 to 2013, Atmos. Environ., 101, 125-133, https://doi.org/10.1016/j.atmosenv.2014.11.024, 2015.

Aiken, A. C., Decarlo, P. F., Kroll, J. H., Worsnop, D. R., Huffman, J. A., Docherty, K. S., Ulbrich, I. M., Mohr, C., Kimmel, J. R., Sueper, D., Sun, Y., Zhang, Q., Trimborn, A., Northway, M., Ziemann, P. J., Canagaratna, M. R., Onasch, T. B., Alfarra, M. R., Prevot, A. S. H., Dommen, J., Duplissy, J., Metzger, A., Baltensperger, U., and Jimenez, J. L.: $\mathrm{O} / \mathrm{C}$ and $\mathrm{OM} / \mathrm{OC}$ ratios of primary, secondary, and ambient organic aerosols with high-resolution time-of-flight aerosol mass spectrometry, Environ. Sci. Technol., 42, 4478-4485, https://doi.org/10.1021/es703009q, 2008.

Akyüz, M. and Çabuk, H.: Gas-particle partitioning and seasonal variation of polycyclic aromatic hydrocarbons in the atmosphere of Zonguldak, Turkey, Sci. Total Environ., 408, 5550-5558, https://doi.org/10.1016/j.scitotenv.2010.07.063, 2010.

Angevine, W. M., White, A. B., and Avery, S. K.: Boundarylayer depth and entrainment zone characterization with a boundary-layer profiler, Bound. Lay. Meteorol., 68, 375-385, https://doi.org/10.1007/BF00706797, 1994.

Bi, X., Sheng, G., Peng, P., Chen, Y., Zhang, Z., and Fu, J.: Distribution of particulate- and vapor-phase $n$ alkanes and polycyclic aromatic hydrocarbons in urban atmosphere of Guangzhou, China, Atmos. Environ., 37, 289-298, https://doi.org/10.1016/S1352-2310(02)00832-4, 2003.

Bi, X., Simoneit, B. R. T., Sheng, G., Ma, S., and Fu, J.: Composition and major sources of organic compounds in urban aerosols, Atmos. Res., 88, 256-265, https://doi.org/10.1016/j.atmosres.2007.11.017, 2008.
Birch, M. and Cary, R.: Elemental carbon-based method for monitoring occupational exposures to particulate diesel exhaust, Aerosol Sci. Tech., 25, 221-241, https://doi.org/10.1080/02786829608965393, 1996.

Castro, L. M., Pio, C. A., Harrison, R. M., and Smith, D. J. T.: Carbonaceous aerosol in urban and rural European atmospheres: estimation of secondary organic carbon concentrations, Atmos. Environ., 33, 2771-2781, https://doi.org/10.1016/S13522310(98)00331-8, 1999.

Chameides, W. L., Yu, H., Liu, S. C., Bergin, M., Zhou, X., Mearns, L., Wang, G., Kiang, C. S., Saylor, R. D., Luo, C., Huang, Y., Steiner, A., and Giorgi, F.: Case study of the effects of atmospheric aerosols and regional haze on agriculture: An opportunity to enhance crop yields in China through emission controls?, P. Natl. Acad. Sci. USA, 96, 13 626-13 633, https://doi.org/10.1073/pnas.96.24.13626, 1999.

Cheng, Y., Li, S.-M., Leithead, A., Brickell, P. C., and Leaitch, W. R.: Characterizations of cis-pinonic acid and $n$-fatty acids on fine aerosols in the Lower Fraser Valley during Pacific 2001 Air Quality Study, Atmos. Environ., 38, 5789-5800, https://doi.org/10.1016/j.atmosenv.2004.01.051, 2004.

Choi, N. R., Lee, S. P., Lee, J. Y., Jung, C. H., and Kim, Y. P.: Speciation and source identification of organic compounds in $\mathrm{PM}_{10}$ over Seoul, South Korea, Chemosphere, 144, 1589-1596, https://doi.org/10.1016/j.chemosphere.2015.10.041, 2016.

Chow, J. C., Watson, J. G., Chen, L.-W. A., Rice, J., and Frank, N. H.: Quantification of $\mathrm{PM}_{2.5}$ organic carbon sampling artifacts in US networks, Atmos. Chem. Phys., 10, 5223-5239, https://doi.org/10.5194/acp-10-5223-2010, 2010.

De La Torre-Roche, R. J., Lee, W.-Y., and Campos-Díaz, S. I.: Soil-borne polycyclic aromatic hydrocarbons in El Paso, Texas: analysis of a potential problem in the United States/Mexico border region, J. Hazard. Mater., 163, 946-958, https://doi.org/10.1016/j.jhazmat.2008.07.089, 2009.

EPA (US Environmental Protection Agency): Provisional assessment of recent studies on health effects of particulate matter exposure (EPA/600/R-12/056F), EPA, Research Triangle Park, North Carolina, 2012.

Fu, P., Kawamura, K., Kobayashi, M., and Simoneit, B. R. T.: Seasonal variations of sugars in atmospheric particulate matter from Gosan, Jeju Island: Significant contributions of airborne pollen and Asian dust in spring, Atmos. Environ., 55, 234-239, https://doi.org/10.1016/j.atmosenv.2012.02.061, 2012.

Gao, M., Guttikunda, S. K., Carmichael, G. R., Wang, Y., Liu, Z., Stanier, C. O., Saide, P. E., and Yu, M.: Health impacts and economic losses assessment of the 2013 severe haze event in Beijing area, Sci. Total Environ., 511, 553-561, https://doi.org/10.1016/j.scitotenv.2015.01.005, 2015.

Gentner, D. R., Jathar, S. H., Gordon, T. D., Bahreini R., Day, D. A., El Haddad, I., Hayes, P. L., Pieber, S. M., Platt, S. M., de Gouw, J., Goldstein, A. H., Harley, R. A., Jimenez, J. L., Prévôt, A. S. H., and Robinson, A. L.: Review of urban secondary organic aerosol formation from gasoline and diesel motor vehicle emissions, Environ. Sci. Technol., 51, 1074-1093, https://doi.org/10.1021/acs.est.6b04509, 2017.

Ghim, Y. S., Chang, Y.-S., and Jung, K.: Temporal and spatial variations in fine and coarse particles in Seoul, Korea, Aerosol Air Qual. Res., 15, 842-852, https://doi.org/10.4209/aaqr.2013.12.0362, 2015. 
Huang, R.-J., Zhang, Y., Bozzetti, C., Ho, K.-F., Cao, J.-J., Han, Y., Daellenbach, K. R., Slowik, J. G., Platt, S. M., Canonaco, F., Zotter, P., Wolf, R., Pieber, S. M., Bruns, E. A., Crippa, M., Ciarelli, G., Piazzalunga, A., Schwikowski, M., Abbaszade, G., SchnelleKreis, J., Zimmermann, R., An, Z., Szidat, S., Baltensperger, U., El Haddad, I., and Prévôt, A. S. H.: High secondary aerosol contribution to particulate pollution during haze events in China, Nature, 514, 218-222, https://doi.org/10.1038/nature13774, 2014.

Irei, S., Takami, A., Sadanaga, Y., Miyoshi, T., Arakaki, T., Sato, K., Kaneyasu, N., Bandow, H., and Hatakeyama, S.: Transboundary secondary organic aerosol in western Japan: An observed limitation of the $f_{44}$ oxidation indicator, Atmos. Environ., 120, 71-75, https://doi.org/10.1016/j.atmosenv.2015.08.070, 2015.

Jimenez, J. L., Canagaratna, M. R., Donahue, N. M., Prevot, A. S. H., Zhang, Q., Kroll, J. H., DeCarlo, P. F., Allan, J. D., Coe, H., Ng, N. L., Aiken, A. C., Docherty, K. S., Ulbrich, I. M., Grieshop, A. P., Robinson, A. L., Duplissy, J., Smith, J. D., Wilson, K. R., Lanz, V. A., Hueglin, C., Sun, Y. L., Tian, J., Laaksonen, A., Raatikainen, T., Rautiainen, J., Vaattovaara, P., Ehn, M., Kulmala, M., Tomlinson, J. M., Collins, D. R., Cubison, M. J., Dunlea, E. J., Huffman, J. A., Onasch, T. B., Alfarra, M. R., Williams, P. I., Bower, K., Kondo, Y., Schneider, J., Drewnick, F., Borrmann, S., Weimer, S., Demerjian, K., Salcedo, D., Cottrell, L., Griffin, R., Takami, A., Miyoshi, T., Hatakeyama, S., Shimono, A., Sun, J. Y., Zhang, Y. M., Dzepina, K., Kimmel, J. R., Sueper, D., Jayne, J. T., Herndon, S. C., Trimborn, A. M., Williams, L. R., Wood, E. C., Middlebrook, A. M., Kolb, C. E., Baltensperger, U., and Worsnop, D. R.: Evolution of Organic Aerosols in the Atmosphere, Science, 326, 1525-1529, https://doi.org/10.1126/science.1180353, 2009.

Jiang, J., Zhou, W., Cheng, Z., Wang, S., He, K., and Hao, J.: Particulate matter distributions in China during a winter period with frequent pollution episodes (January 2013), Aerosol Air Qual. Res., 15, 494-503, https://doi.org/10.4209/aaqr.2014.04.0070, 2015.

Kang, C.-M., Lee, H. S., Kang, B.-W., Lee, S.-K., and Sunwoo, Y.: Chemical characteristics of acidic gas pollutants and $\mathrm{PM}_{2.5}$ species during hazy episodes in Seoul, South Korea, Atmos. Environ., 38, 4749-4760, https://doi.org/10.1016/j.atmosenv.2004.05.007, 2004.

Kang, C.-M., Kang, B.-W., and Lee, H. S.: Source identification and trends in concentrations of gaseous and fine particulate principal species in Seoul, South Korea, J. Air Waste Manage., 56, 911921, https://doi.org/10.1080/10473289.2006.10464506, 2006.

Kang, E., Han, J., Lee, M., Lee, G., and Kim, J. C.: Chemical characteristics of size-resolved aerosols from Asian dust and haze episode in Seoul Metropolitan City, Atmos. Res., 127, 34-46, https://doi.org/10.1016/j.atmosres.2013.02.002, 2013.

Kawamura, K. and Kaplan, I. R.: Motor exhaust emission as a primary source of dicarboxylic acids in Los Angeles ambient air, Environ. Sci. Technol., 21, 105-110, https://doi.org/10.1021/es00155a014, 1987.

Kim, B. M., Seo, J., Kim, J. Y., Lee, J. Y., and Kim, Y.: Transported vs. local contributions from secondary and biomass burning sources to $\mathrm{PM}_{2.5}$, Atmos. Environ., 144, 24-36, https://doi.org/10.1016/j.atmosenv.2016.08.072, 2016.

Kim, D., Jung, J., Lee, H., Choi, S.-H., and Lee, S.: Characterization of sampling artifacts in the measurement of carbonaceous particles using high- and low-volume sam- plers in Daejeon, Korea, Atmos. Environ., 139, 157-166, https://doi.org/10.1016/j.atmosenv.2016.05.029, 2016.

Kim, J.-H., Choi, D.-R., Koo, Y.-S., Lee, J.-B., and Park, H.J.: Analysis of domestic and foreign contributions using DDM in CMAQ during particulate matter episode period of February 2014 in Seoul, J. Kor. Soc. Atmos. Environ., 32, 8299, https://doi.org/10.5572/KOSAE.2016.32.1.082, 2016 (in Korean).

Kim, J. Y., Ghim, Y. S., Song, C. H., Yoon, S. C., and Han, J. S.: Seasonal characteristics of air masses arriving at Gosan, Korea, using fine particle measurements between November 2001 and August 2003, J. Geophys. Res., 112, D07202, https://doi.org/10.1029/2005JD006946, 2007.

Kim, Y., Kim, S.-W., Yoon, S.-C., Kim, M.-H., and Park, K.-H.: Aerosol properties and associated regional meteorology during winter pollution event at Gosan climate observatory, Korea, Atmos. Environ., 85, 9-17, https://doi.org/10.1016/j.atmosenv.2013.11.041, 2014.

Kundu, S., Kawamura, K., Andreae, T. W., Hoffer, A., and Andreae, M. O.: Molecular distributions of dicarboxylic acids, ketocarboxylic acids and $\alpha$-dicarbonyls in biomass burning aerosols: implications for photochemical production and degradation in smoke layers, Atmos. Chem. Phys., 10, 2209-2225, https://doi.org/10.5194/acp-10-2209-2010, 2010.

Lagler, F., Belis, C., and Borowiak, A.: A quality assurance and control program for $\mathrm{PM}_{2.5}$ and $\mathrm{PM}_{10}$ measurements in European Air Quality Monitoring Networks (EUR 24851 EN), Joint Research Centre, Institute for Environment and Sustainability, Publications Office of the European Union, Luxembourg, 118 pp., 2011.

Lee, H.-J., Kim, S.-W., Brioude, J., Cooper, O. R., Frost, G. J., Kim, C.-H., Park, R. J., Trainer, M., and Woo, J-H.: Transport of $\mathrm{NO}_{x}$ in East Asia identified by satellite and in situ measurements and Lagrangian particle dispersion model simulations, J. Geophys. Res., 119, 2574-2596, https://doi.org/10.1002/2013JD021185, 2014.

Lee, J., Cho, K. S., Jeon, Y., Kim, J. B., Lim, Y.-R., Lee, K., and Lee, I.-S.: Characteristics and distribution of terpenes in South Korean forests, J. Ecol. Environ., 41, 1-19, https://doi.org/10.1186/s41610-017-0038-z, 2017.

Lee, S., Ho, C.-H., and Choi, Y.-S.: High-PM 10 concentration episodes in Seoul, Korea: Background sources and related meteorological conditions, Atmos. Environ., 45, 7240-7247, https://doi.org/10.1016/j.atmosenv.2011.08.071, 2011.

Lee, S., Ho, C.-H., Lee, Y. G., Choi, H.-J., and Song, C.K.: Influence of transboundary air pollutants from China on the high- $\mathrm{PM}_{10}$ episode in Seoul, Korea for the period October 16-20, 2008, Atmos. Environ., 77, 430-439, https://doi.org/10.1016/j.atmosenv.2013.05.006, 2013.

Li, M., Zhang, Q., Kurokawa, J., Woo, J.-H., He, K. B., Lu, Z., Ohara, T., Song, Y., Streets, D. G., Carmichael, G. R., Cheng, Y. F., Hong, C. P., Huo, H., Jiang, X. J., Kang, S. C., Liu, F., Su, H., and Zheng, B.: MIX: a mosaic Asian anthropogenic emission inventory under the international collaboration framework of the MICS-Asia and HTAP, Atmos. Chem. Phys, 17, 935-963, https://doi.org/10.5194/acp-17-935-2017, 2017.

Liang, J. Y. and Jacobson, M. Z.: A study of sulfur dioxide oxidation pathways over a range of liquid water contents, $\mathrm{pH}$ values, and temperatures, J. Geophys. Res., 104, 13749-13769, https://doi.org/10.1029/1999JD900097, 1999. 
Lim, Y. B., Kim, H., Kim, J. Y., and Turpin, B. J.: Photochemical organonitrate formation in wet aerosols. Atmos. Chem. Phys., 16, 12631-12647, https://doi.org/10.5194/acp-16-126312016, 2016

Lim, Y. B., Seo, J., Kim, J. Y., and Turpin, B. J.: Aqueous-phase organonitrate formation from photochemical aging of wet urban particles, in preparation, 2017.

NIER (National Institute of Environmental Research): National air pollutants emission, 2013 (NIER-GP2015-240), NIER, Incheon, South Korea, available at: http://webbook.me.go.kr/DLi-File/ NIER/09/021/5609643.pdf (last access: 6 October 2016), 2015 (in Korean).

NIER (National Institute of Environmental Research): Annual report of ambient air quality in Korea, 2015 (NIER-GP2016-122), NIER, Incheon, South Korea, available at: http://webbook.me. go.kr/DLi-File/NIER/09/021/5618423.pdf, last access: 6 October 2016 (in Korean).

Nisbet, I. C. T. and LaGoy, P. K.: Toxic equivalency factors (TEFs) for polycyclic aromatic hydrocarbons (PAHs), Regul. Toxicol. Pharm., 16, 290-300, https://doi.org/10.1016/02732300(92)90009-X, 1992.

Oh, H.-R., Ho, C.-H., Kim, J., Chen, D., Lee, S., Choi, Y.-S., Chang, L.-S., and Song, C.-K.: Long-range transport of air pollutants originating in China: A possible major cause of multi-day high- $\mathrm{PM}_{10}$ episodes during cold season in Seoul, Korea, Atmos. Environ., 109, 23-30, https://doi.org/10.1016/j.atmosenv.2015.03.005, 2015.

Oh, I. B., Kim, Y. K., Hwang, M. K., Kim, C. H., Kim, S., and Song, S. K.: Elevated ozone layers over the Seoul Metropolitan Region in Korea: Evidence for long-range ozone transport from eastern China and its contribution to surface concentrations, J. Appl. Meteorol. Clim., 49, 203-220, https://doi.org/10.1175/2009JAMC2213.1, 2010.

Oliveira, C., Martins, N., Tavares, J., Pio, C., Cerqueira, M., Matos, M., Silva, H., Oliveira, C., and Camões, F.: Size distribution of polycyclic aromatic hydrocarbons in a roadway tunnel in Lisbon, Portugal, Chemosphere, 83, 1588-1596, https://doi.org/10.1016/j.chemosphere.2011.01.011, 2011.

Park, J.-S., Song, I.-H., Park, S.-M., Shin, H.-J., and Hong, Y.-D.: Characteristics of submicron particle during high concentration episodes in spring, 2014 at Seoul, Korea, using the Aerosol Mass Spectrometer, J. Korean Soc. Environ. Analysis, 18, 12-25, 2015 (in Korean).

Park, S.-S., Jung, S.-A., Gong, B.-J., Cho, S.-Y., and Lee, S.J.: Characteristics of $\mathrm{PM}_{2.5}$ haze episodes revealed by highly time-resolved measurements at an air pollution monitoring supersite in Korea, Aerosol Air Qual. Res., 13, 957-976, https://doi.org/10.4209/aaqr.2012.07.0184, 2013.

Pelly, J. L. and Hoskins, B. J.: A new perspective on blocking, J. Atmos. Sci., 60, 743-755, https://doi.org/10.1175/15200469(2003)060<0743:ANPOB>2.0.CO;2, 2003.

Pies, C., Hoffmann, B., Petrowsky, J., Yang, Y., Ternes, T. A., and Hofmann, T.: Characterization and source identification of polycyclic aromatic hydrocarbons (PAHs) in river bank soils, Chemosphere, 72, 1594-1601, https://doi.org/10.1016/j.chemosphere.2008.04.021, 2008.

Pope, C. A. and Dockery, D. W.: Health effects of fine particulate air pollution: lines that connect, J. Air Waste Manage., 56, 709-742, https://doi.org/10.1080/10473289.2006.10464485, 2006.
Ramanathan, V., Crutzen, P. J., Lelieveld, J., Mitra, A. P., Althausen, D., Anderson, J., Andreae, M. O., Cantrell, W., Cass, G. R., Chung, C. E., Clarke, A. D., Coakley, J. A., Collins, W. D., Conant, W. C., Dulac, F., Heintzenberg, J., Heymsfield, A. J., Holben, B., Howell, S., Hudson, J., Jayaraman, A., Kiehl, J. T., Krishnamurti, T. N., Lubin, D., McFarquhar, G., Novakov, T., Ogren, J. A., Podgorny, I. A., Prather, K., Priestley, K., Prospero, J. M., Quinn, P. K., Rajeev, K., Rasch, P., Rupert, S., Sadourny, R., Satheesh, S. K., Shaw, G. E., Sheridan, P., and Valero, F. P. J.: Indian Ocean experiment: an integrated analysis of the climate forcing and effects of the great Indo-Asian haze, J. Geophys. Res., 106, 28371-28398, https://doi.org/10.1029/2001JD900133, 2001.

Rogge, W. F., Mazurek, M. A., Hildemann, L. M., Cass, G. R., and Simoneit, B. R. T.: Quantification of urban organic aerosols at a molecular level: identification, abundance and seasonal variation, Atmos. Environ., 27, 1309-1330, https://doi.org/10.1016/09601686(93)90257-Y, 1993.

Rogge, W. F., Hildemann, L. M., Mazurek, M. A., Cass, G. R., and Simoneit, B. R. T.: Sources of fine organic aerosol. 9. Pine, oak, and synthetic log combustion in residential fireplaces, Environ. Sci. Technol., 32, 13-22, https://doi.org/10.1021/es960930b, 1998.

Seinfeld, J. H. and Pandis, S. N.: Atmospheric chemistry and physics: From air pollution to climate change, 2nd Edn., John Wiley \& Sons, Inc., Hoboken, New Jersey, 2006.

Seo, J., Youn, D., Kim, J. Y., and Lee, H.: Extensive spatiotemporal analyses of surface ozone and related meteorological variables in South Korea for the period 1999-2010, Atmos. Chem. Phys., 14, 6395-6415, https://doi.org/10.5194/acp-14-6395-2014, 2014.

Shin, H.-J., Lim, Y.-J., Kim, J.-H., Jung, H.-J., Park, S.-M., Park, J.-S., Song, I.-H., Seo, S.-J., Hong, Y.-D., and Han, J.-S.: The Characteristics of long term high PM episode occurred in Feb. 2014, J. Korean Soc. Urban Environ., 14, 223-232, 2014 (in Korean).

Simoneit, B. R. T.: Organic matter of the troposphere - V: application of molecular marker analysis to biogenic emissions into the troposphere for source reconciliations, J. Atmos. Chem., 8, 251-275, https://doi.org/10.1007/BF00051497, 1989.

Simoneit, B. R. T., Sheng, G., Chen, X., Fu, J., Zhang, J., and $\mathrm{Xu}, \mathrm{Y}$.: Molecular marker study of extractable organic matter in aerosols from urban areas of China, Atmos. Environ., 25, 21112129, https://doi.org/10.1016/0960-1686(91)90088-O, 1991.

Simoneit, B. R. T., Schauer, J. J., Nolte, C. G., Oros, D. R., Elias, V. O., Fraser, M. P., Fraser, M. P., Rogge, W. F., and Cass, G. R.: Levoglucosan, a tracer for cellulose in biomass burning and atmospheric particles, Atmos. Environ., 33, 173-182, https://doi.org/10.1016/S1352-2310(98)00145-9, 1999.

Squizzato, S., Masiol, M., Brunelli, A., Pistollato, S., Tarabotti, E., Rampazzo, G., and Pavoni, B.: Factors determining the formation of secondary inorganic aerosol: a case study in the Po Valley (Italy), Atmos. Chem. Phys., 13, 1927-1939, https://doi.org/10.5194/acp-13-1927-2013, 2013.

Stull, R. B.: An Introduction to Boundary Layer Meteorology, Kluwer Academic Publishers, Dordrecht, 1988.

Sun, Y., Jiang, Q., Wang, Z., Fu, P., Li, J., Yang, T., and Yin, Y.: Investigation of the source and evolution processes of severe haze pollution in Beijing in January 2013, J. Geophys. Res., 119, 4380-4398, https://doi.org/10.1002/2014JD021641, 2014. 
Tao, M., Chen, L., Su, L., and Tao, J.: Satellite observation of regional haze pollution over the North China Plain, J. Geophys. Res., 117, D12203, https://doi.org/10.1029/2012JD017915, 2012.

Tobiszewski, M. and Namieśnik, J.: PAH diagnostic ratios for the identification of pollution emission sources, Environ. Pollut., 162, 110-119, https://doi.org/10.1016/j.envpol.2011.10.025, 2012.

Turpin, B. J. and Huntzicker, J. J.: Identification of secondary organic aerosol episodes and quantitation of primary and secondary organic aerosol concentrations during SCAQS, Atmos. Environ., 29, 3527-3544, https://doi.org/10.1016/1352-2310(94)00276-Q, 1995.

Tyrlis, E. and Hoskins, B. J.: Aspects of a Northern Hemisphere atmospheric blocking climatology, J. Atmos. Sci., 65, 1638-1652, https://doi.org/10.1175/2007JAS2337.1, 2008.

Wang, H., Tan, S.-C., Wang, Y., Jiang, C., Shi, G.-Y., Zhang, M.-X., and Che, H.-Z.: A multisource observation study of the severe prolonged regional haze episode over eastern China in January 2013, Atmos. Environ., 89, 807-815, https://doi.org/10.1016/j.atmosenv.2014.03.004, 2014a.

Wang, H., Xu, J., Zhang, M., Yang, Y., Shen, X., Wang, Y., Chen, D., and Guo, J.: A study of the meteorological causes of a prolonged and severe haze episode in January 2013 over central-eastern China, Atmos. Environ., 98, 146-157, https://doi.org/10.1016/j.atmosenv.2014.08.053, 2014b.

Wang, J., Wang, S., Jiang, J., Ding, A., Zheng, M., Zhao, B., Wong, D.C., Zhou, W., Zheng, G., Wang, L., Pleim, J., and Hao, J.: Impact of aerosol-meteorology interactions of fine particle pollution during China's severe haze episode in January 2013, Environ. Res. Lett., 9, 094002, https://doi.org/10.1088/17489326/9/9/094002, 2014.

WHO (World Health Organization): WHO Air quality guidelines for particulate matter, ozone, nitrogen dioxide and sulfur dioxide - Global update 2005, WHO, Geneva, Switzerland, 2006.
Yunker, M. B., Macdonald, R. W., Vingarzan, R., Mitchell, R. H., Goyette, D., and Sylvestre, S.: PAHs in the Fraser River basin: a critical appraisal of PAH ratios as indicators of PAH source and composition, Org. Geochem., 33, 489-515, https://doi.org/10.1016/S0146-6380(02)00002-5, 2002.

Zhang, J. K., Sun, Y., Liu, Z. R., Ji, D. S., Hu, B., Liu, Q., and Wang, Y. S.: Characterization of submicron aerosols during a month of serious pollution in Beijing, 2013, Atmos. Chem. Phys., 14, 2887-2903, https://doi.org/10.5194/acp-14-2887-2014, 2014.

Zhang, Y.-L., Kawamura, K., Fu, P. Q., Boreddy, S. K. R., Watanabe, T., Hatakeyama, S., Takami, A., and Wang, W.: Aircraft observations of water-soluble dicarboxylic acids in the aerosols over China, Atmos. Chem. Phys., 16, 6407-6419, https://doi.org/10.5194/acp-16-6407-2016, 2016.

Zhang, Y. Y., Müller, L., Winterhalter, R., Moortgat, G. K., Hoffmann, T., and Pöschl, U.: Seasonal cycle and temperature dependence of pinene oxidation products, dicarboxylic acids and nitrophenols in fine and coarse air particulate matter, Atmos. Chem. Phys., 10, 7859-7873, https://doi.org/10.5194/acp-107859-2010, 2010.

Zhao, X. J., Zhao, P. S., Xu, J., Meng, W., Pu, W. W., Dong, F., He, D., and Shi, Q. F.: Analysis of a winter regional haze event and its formation mechanism in the North China Plain, Atmos. Chem. Phys., 13, 5685-5696, https://doi.org/10.5194/acp13-5685-2013, 2013.

Zheng, G. J., Duan, F. K., Su, H., Ma, Y. L., Cheng, Y., Zheng, B., Zhang, Q., Huang, T., Kimoto, T., Chang, D., Pöschl, U., Cheng, Y. F., and He, K. B.: Exploring the severe winter haze in Beijing: the impact of synoptic weather, regional transport and heterogeneous reactions, Atmos. Chem. Phys., 15, 2969-2983, https://doi.org/10.5194/acp-15-2969-2015, 2015. 